Article

\title{
Overtourism and Medium Scale Sporting Events Organisations-the Perception of Negative Externalities by Host Residents
}

\author{
Joanna Poczta ${ }^{1, *(\mathbb{D}}$, Agata Dąbrowska ${ }^{1}$, Marek Kazimierczak ${ }^{1}$, François Gravelle ${ }^{2}$ and \\ Ewa Malchrowicz-Mośko ${ }^{1}$ (D) \\ 1 Department of Sports Tourism, Faculty of Sports Science, Poznan University of Physical Education, \\ 61-871 Poznan, Poland; zagata.pl@gmail.com (A.D.); kazimierczak@awf.poznan.pl (M.K.); \\ malchrowicz@awf.poznan.pl (E.M.-M.) \\ 2 School of Human Kinetics, Faculty of Health Sciences, University of Ottawa, 125 University Private, Ottawa, \\ ON K1N 6N5, Canada; fgravel@uottawa.ca \\ * Correspondence: jpoczta@awf.poznan.pl
}

Received: 15 January 2020; Accepted: 23 March 2020; Published: 2 April 2020

check for updates

\begin{abstract}
The main purpose of this study is to investigate the influence of non-mega sporting events on the perception of negative externalities of host residents. The detailed aim of the study was to examine whether the inhabitants of the city feel the negative effects of organizing sporting events (communication problems or inappropriate behavior of supporters) and do they believe that these events increase the level of crime in the city or, despite these inconveniences, they are satisfied with the organization of sporting events in their place of residence. The case study is the city of Poznan and two, well-known events in this agglomeration. The first one is the Poznan Half Marathon-medium scale mass event, the second one is Cavaliada-elite international equestrian event. The theoretical part of this article presents the meaning of sporting events organization for tourism industry and indicates the positive and negative effects this kind of tourism brings to host cities. The whole refers to the theoretical foundations of the term of "overtourism". The second part of the manuscript presents empirical research results, between 774 active and passive participants, which was conducted by the method of diagnostic survey. The results of this research show that both athletes as well as fans of the Half Marathon said that the Poznan Half Marathon event causes bothersome communication problems in the city and some other social problems. The inhabitants only experience minor inconveniences that felt as a result of organizing sporting events in the city. The negative impact of Cavaliada was very low. For checking the differences between the two examined groups of respondents: Half Marathon fans and Cavaliada fans, Chi-square test and U Mann Whitney's test was used. The participants feel bothersome communication problems that cause the Half Marathon and have an average level of dissatisfaction higher than the average level of dissatisfaction of Cavaliada participants. Moreover, the participants in the Half Marathon have an average level of satisfaction with the organization of sports events in Poznan significantly lower than the average level of satisfaction of Cavaliada participants. Therefore, an elite equestrian sporting event is less burdensome for its residents and gives them more satisfaction.
\end{abstract}

Keywords: non-mega sports events; overtourism; sports tourism; quality of life of hosts; social impact of sports events; sustainability 


\section{Introduction}

\subsection{Negative Implications of Sporting Events and Overtourism}

Sports tourism is a deeply interdisciplinary phenomenon. As mentioned above, it affects both residents and tourists in the economic, ecological, social and cultural dimensions. It also impacts positive and negative in psychological, institutional, political and planning levels. However, the larger the event, the greater the impact. Weed and Bull [1] claims that three key components interact to create value in sports tourism: the places involved, the activities undertaken, the motivations to participate. Places where tourists stay and their activities have specific characteristics (beautiful scenery, attractive landscapes, monuments etc.) which are a subject of various interpretations [2-4]. On the other hand, the number of tourists and their activities can destroy sociocultural, physical or economic resources and reduce the quality of tourist's satisfaction. That is why, determining and respecting the carrying capacity of destinations becomes a necessity in tourism planning $[5,6]$. Popular tourist destinations around the world have reached a tourism tipping point. To describe these tourism disturbances (not only in sports tourism), the term overtourism, tourism phobia, overcrowded locations or visitor pressure has rapidly been popularized [7-11]. The perception of city tourism has changed dramatically. Destinations are being saturated with visitors. The critical point begins at the place where there is an imbalance between the perception of positive and negative effects of tourism for the inhabitants [11,12]. Infrastructure like roads, public transportation, cultural attractions and other services which were created primarily for local use, suffer under increasing number of tourists. The growing popularity of transport services, online accommodation and a desire to see the authentic, everyday city life has meant that tourism activities become further intertwined with local life, also outside of the main tourist areas in cities $[13,14]$. Such developments have led to calls from residents to deal with tourism growth and protests have been observed for example in popular destinations like Venice or Barcelona. Although this problem is most evident in European cities, similar sentiments have also been reported elsewhere, such as tropical islands, backpacker ghettos or even slums $[13,15]$. Despite of the growing popularity, "overtourism" is still not clearly defined [13]. The term describes destinations where hosts or guests, locals or visitors, feel that the quality of life and the quality of the experience in the area has deteriorated unacceptably. Moreover, "overtourism" describes the situation in which the impact of tourism exceeds ecological, physical, social, psychological, political and economic capacity thresholds and causes the loss of authenticity and imply a significant risk to the future attractiveness of a destination. There are many examples where the cultural and natural heritage of a place is at risk or where costs of living and real estate have substantially increased and caused a decline in quality of life. It is the opposite of responsible tourism which is about using tourism to make better places to live in and better places to visit [16]. The uncontrolled development of tourism can cause significant damage to air and water quality, landscapes, seascapes, as well as the living conditions of residents, causing economic inequalities and social exclusion, as well as many other issues [17]. Dissatisfaction with overtourism on the part of local residents might mobilize forces to prevent tourism from developing and increasing at its destination. The dissatisfaction of visitors can reduce the number of visits to the destination, thus harming its economic sustainability [11].

Sports tourism is not always manifest in the mass movement of large numbers of tourists. Many authors (Hautbois, Djaballah, Desbordes; Hall; Hallmann; Barclay; Taks; Lee; Taylor; Preuss; Kim, Jun, Walker, Drane) have studied the influence of mega sporting events on all the above-mentioned planes of human life, both residents of reception areas and passive participants of sporting events, fans and athletes. They describe sports event organization as a mechanism used to tackle social problems. Of course, sports tourism contributes significantly in the development of a society [18-26]. Unfortunately, to the authors knowledge, there are no in-depth studies that would indicate a significant, negative impact of organization non-mega sporting events on environmental, social life of residents or culture of the place. Residents are an important part of the success of a sporting event and their opinion is significant, even if we are talking about small sporting venture. However, according to Kim 
and Petrik or Ohmann [27-29], there is a certain degree of inconsistency in the use of the perception of residents to measure the impact of the event due to the fact that it often lacks objectivity because of the subjective feature's views of residents. However, Jönsson [30] refers to the credibility of local opinions in the field of social impact assessment. He finds it difficult to investigate because their perception may change over time. Performing a longitudinal study would allow assessment over a period of time, thus recording any changes in perceptions by residents. It is also important, for the commercial success of any touristic region, to monitor the satisfaction of visitors or so-called tourist social ability [6].

\subsection{The Benefits of Sporting Events Organisation}

Sports tourism is not only a sum of sport and tourism. It is a complex phenomenon, similar and different from sport and tourism individually. It is multifaceted and exists under a variety of forms and names [1,31-34]. Sports tourists travel to observe sporting activities, to participate in sport and to visit sports attractions (stadiums, sports museums, recreation areas, etc.). Depending on active or passive participation and motivational factors, sports tourists encounter different experiences as the ultimate value they are seeking [35-38]. Mega and small scale sports tourism has the potential to contribute to the social, cultural, economic and infrastructural development of the host country or city. Visitors generate tremendous activity through different forms of expenditure on sporting and non-sporting activities. Cities provide them with a number of multifunctional, complex, multiuser environments. They are able to simultaneously receive domestic and international tourists but also business tourists and people visiting friends and relatives (VFR) [13].

The organization of sporting events is widely recognized as a method of promoting touristic cities and addressing seasonality in destinations [39,40]. They are the most obvious manifestation of sporting activities, gathering two groups of participants: competitors and spectators. Events usually offer a lot of entertainment opportunities for residents and visitors [41] and are seen as one of the most sustainable economic growth strategies for cities, as a driver for economic recovery of great value [42]. The fact that cities tend to have good infrastructure facilities and already host a diverse and dynamic population is obvious and suggests that they will better cope with increasing tourist numbers than other, well-known destinations [13]. Most of the literature follows the relevance of sporting events stems directly from their impact on local, regional and national economies [43-45] and distinguishes between the economic, sociocultural and environmental impacts of sporting events [46-50]. They stimulate the dynamic development of tourism in cities. The phenomenon is very wide and many researchers are trying to carry out scientific analyses to check whether the positive or negative effects of organizing a sports event in a given tourist destination prevail [51-53]. According to Hall [19], the impact of sports tourism affects changes in the value systems of individuals, local communities or entire societies caused by sports travel, changes in types of behavior of tourists and the local population, their social structures, lifestyle and level of quality of life. Due to the effects of a given sporting event are also called its "legacy" - what will remain after it, especially for the local community [19,54-56].

The organization of sporting events includes numerous benefits on an economic, social, cultural and environmental level as new investments, new employment and increased tourism figures and tax revenues [48,57-62]-Table 1. Positive example is new material benefits building: new roads and highways, ultramodern sports stadiums or the development of small sports and tourists' infrastructure in smaller towns. We can observe also some non-monetary effects like improvements to a country's or destination's image abroad and among the fans coming to events [20,63]. It can translate into its tourist attractiveness or promotion of the sport and healthy lifestyle among citizens. An important aspect is also the organizational competence acquired during the preparation of the event $[64,65]$. Sporting events can have the positive influence on local residents' quality of life, people who believe in the importance of physical activity and the ability to shape their own social environment, increase sports participation, enhance social cohesion or generate interest in a foreign culture $[25,28,66,67]$. Positive environmental impacts could only have a place when new sports infrastructure is built on devastated land $[58,68]$. 
Table 1. Potential effects of sport tourism events.

\begin{tabular}{|c|c|c|}
\hline Type of Impact & Positive & Negative \\
\hline Economic & $\begin{array}{l}\text {-financial benefits of organizing major sporting events } \\
\text { (supporters' expenses, sports sponsorship, advertisers, etc.) } \\
\text { - financial benefits resulting from the development of tourism } \\
\text { after the event (e.g., thanks to improving the image of the region) } \\
\text { — development of public as well as tourist and sports infrastructure }\end{array}$ & $\begin{array}{l}\text {-excessively high costs of organizing large } \\
\text { sporting events } \\
\text { —crowding out phenomenon } \\
\text { —too high investment costs in infrastructure, } \\
\text { the problem of "white elephants" }\end{array}$ \\
\hline Sociocultural & $\begin{array}{c}\text {-increased sense of national pride } \\
\text {-integration of the local community } \\
\text {-development or strengthening of regional identity } \\
\text {-intercultural communication } \\
\text { - diffusion of forms of sports cultures } \\
\text { —the impact of sports tourism on the development of different } \\
\text { forms of tourism, } \\
\text { —sports heritage, e.g., development of sports volunteering } \\
\text { — the possibility of changing a healthy lifestyle as a result of } \\
\text { observing others } \\
\text {-opportunity for entertainment (increase in the level of happiness } \\
\text { and quality of life) } \\
\text {-development of sports museums-potential tourist attractions in } \\
\text { the future } \\
\text { —-the opportunity to present regional cultural heritage. }\end{array}$ & $\begin{array}{c}\text {-difficulties in the normal operations of the } \\
\text { local community - traffic jams, congestion, } \\
\text { price increases, acts of intentional } \\
\text { vandalism (reduced quality of life), etc. } \\
\text { - resettlement of the local population } \\
\text { — globalization of sport (loss of regional } \\
\text { sports cultures due to the domination } \\
\text { of others) } \\
\text {-improper behavior of supporters, e.g., } \\
\text { presenting nationalist attitudes } \\
\text { - the impact of sports tourism on the } \\
\text { development of different forms of tourism, } \\
\text { e.g., sex tourism }\end{array}$ \\
\hline Ecological & $\begin{array}{l}\text { - the possibility of implementing sustainable development } \\
\text { programs-increasing public awareness (assuming its promotion } \\
\text { by competition organizers) } \\
\text { —revitalization of urban space (parks, health paths, etc.) }\end{array}$ & $\begin{array}{c}\text {-noise } \\
\text { - littering of areas of outstanding natural } \\
\text { value, sometimes protected areas } \\
\text { - transformation of natural areas for sports } \\
\text { infrastructure } \\
\text {-increased emission of toxic substances }\end{array}$ \\
\hline
\end{tabular}

Source: Malchrowicz-Mośko [8].

The effects have been observed at a number of Olympic Games. "Barcelona effect" is worth mentioning in this place as an example of a positive legacy of sporting events. Due to excellent organization and promotion of the Olympics Games, the city became recognizable across the whole world as a business center and, mostly, a touristic destination. Although the Olympic Games left Barcelona deficit, the capital of Catalonia benefited by the event in a long-term perspective $[64,68]$. Over the years this impact is positive but also negative. Specifically, the city's residents experience inconvenience related to the influx of tourists [67,69-72]. Barcelona has clearly become a major urban tourist destination and a cultural tourism center [73,74]. The 1992 great event led the city to present many dimensions which make up its personality and at the same time served to modernize them and open them to the future [74]. Currently, the city is the main recipient of international tourism income in the country. Barcelona's shops and stores receive over $15 \%$ of the total expenditure of foreign visitors in Spain, which is the second-largest tourist destination in the world, after France [66-76].

\subsection{The Costs and Negative Impacts of Sporting Events Organisation}

In most cases, negative (Table 1) legacies are often neglected when planning and evaluating an event [77]. Sporting events could also produce excessive spending, increased taxes and higher costs of living for residents $[25,78,79]$. Even if social and cultural impacts are more difficult to measure and manage $[53,80,81]$ cultural conflicts between residents and tourists are seen. Moreover, security risks, hooliganism or traffic problems seem to be among the most relevant negative impacts for residents $[19,25,46,49,51,79]$. Another issue is the well thought-out and planned construction of a new sports tourism infrastructure. If this is not possible, it can cause environmental damage to the host community $[46,51]$ and many people gathered at an event generate air and water pollution, an increased amount of waste and noise levels $[46,79,82]$.

The opposite of Barcelona's example is the Summer Olympic Games in Montreal in 1976, when the most often cited the legacy of, is debt. The Olympic Stadium was supposed to cost $\$ 250$ million but ultimately it cost $\$ 1.4$ billion. The city did not pay off until November 2006-30 years after the closing ceremony [73,75]. Haynes [83] gives examples (not positive for tourism) of the 1984 Los Angeles Games and the 2000 Sydney Olympic Games. In Los Angeles, although hotels were occupied at that 
time, the Disney resort, Universal Studios and the Six Flags Magic Mountain all reported reduced interest from tourists [83]. During the 2000 Olympic Games in Sydney, the hotel occupancy in Sydney and Adelaide was high but in hotels elsewhere in Australia was significantly lower [84]. The British media presented this trend as a major problem for tourist attractions and hotels in central London in 2012 when a few weeks before the event, it turned out that a third of hotel rooms in London were unsold [83,84]. It is estimated that during the 2002 South Korea FIFA World Cup, the number of current foreign tourists was the same as the number of tourists who visited during the same period the previous year [85]. The Atlanta Olympic Games experienced crowding out effects, concluding that, in a part of the city a short distance from the Olympic Park, many hotels and restaurants a significant reduction in income [85]. The host of the Singapore Formula One Grand Prix have noted the same problem. Retailers and restaurateurs near the track have complained about a fall in custom as residents avoid the area [86].

Authors Wilson and Liu [84] conducted factor analysis which revealed six negative impact factors: travel inconvenience (the most negative), price inflation, security and crime concern, risk of disease and pollution and the last factor-damage to the environment. Respondents did not have a clear opinion on the impact of the event on the deterioration of the quality of services. It was found that travel inconvenience and price inflation were significantly but negatively related to the intention to travel [84]. Of course, the organization of major sporting events carries the risk of price inflation, vandalism, terrorism, pollution and environmental problems. Therefore, the negative effects of great events cannot be ignored. But the above-mentioned impacts could be very intensive but depend on the size of event. Large-scale sporting events are globally attractive to tourists as well as the media $[47,87]$ but negative impacts are more visible.

Most research in this problem has focused on mega sporting events (MSEs). There is little research on organizing smaller non-mega sports events (NMSEs) that reflects on how these smaller types of events can potentially contribute to benefits and losses residents of local people [22]. For example, Djaballah, Hautbois and Desbordes checked how local governments make sense of small scale sporting events' social impacts. Their case study were local sports officials from 25 medium French cities [88]. The analyzed small scale events are mainly perceived by researchers as a stimulator of tourism development and a chance for the general development of cities and regions [88,89]. Many studies are primarily concerned with identifying motivations and benefits for active or inactive participants of events (and less often for residents) [90-95] but in the context of impact on destinations, the authors write about protected areas [96]. Recently, there have also been publications in which attention is devoted not only to modern sporting events but also to historical sporting events in the field of impact on the local society $[97,98]$. Sports events are very often the most important goal in the tourism strategies of many cities. Major sports events not only attract participants and spectators but also have the capacity to change the image of cities and encourage future tourism which have an influence on economies, local communities, sociocultural context and ecology for many years after the event has been staged [99]. In the last two decades, there has been a lot of research addressing a variety results [100-103] of mega spectator sporting events [18].

The subject of the presented manuscript closely refer to this special issue, especially that in the tourism literature, overtourism in connection with sporting events organization has been discussed. The effect of excessive tourism is an increase in the aggressive commercialization, price of services, rental fees and real estate and depopulation in cities and districts exploited by sports tourism. In cities with a long history, it causes the gentrification of historical areas. Overtourism as a negative phenomenon observed during the organization of sports events results in the limits of socio-psychological capacity not only residents being exceeded but also tourists. That is why we see the link between our research and this special issue, especially that so many cities are seeking the right to organize big events such as the Summer or Winter Olympic Games, the FIFA World Cup, the Formula One Grand Prix hoping for far-reaching changes benefit their host community [104]. Small scale sporting events, if respectively designed and implemented in practice, also have potential to benefit hosting communities [105-109] 
but are not so burdensome for residents. However, the larger the event, the greater the impact, which is why in the event planning process, consideration should be given to developing contingency solutions for major risks [110].

The purpose of this manuscript is to pay attention to the negative effects of organization medium and small scale sporting events from the perspective of a participating resident, since such events have not yet been studied. Indeed, what impact do they have on the perception of participating inhabitants? Whether the inhabitants of the city feel the negative effects of organizing sporting events (communication problems or inappropriate behavior of supporters) and do they believe that these events increase the level of crime in the city or, despite these inconveniences, are they satisfied with the organization of sporting events in their place of residence? How are these impacts perceived by participants who are also residents of the city?

Structure of the paper is as follows. The first part shows the literature review of negative implications of sporting events and overtourism, the costs and benefits of sporting events organization. The second part presents the method description—diagnostic survey by the authorship questionnaire submitted to the host's participants $(n=774)$ of the two, well-known events in Poznan: Half Marathon: medium scale mass event and Cavaliada and elite international equestrian event. The second part of the article presents results of this empirical research. Finally, we present the results of this empirical research, our findings and discuss their theoretical and managerial implications.

\section{Aim of the Study}

The main purpose of this study is to investigate the impact of non-mega sporting events on the perception of negative externalities of host residents. The detailed aim of the study was to examine whether the inhabitants of the city feel the negative effects of organizing sporting events (communication problems or inappropriate behavior of supporters) and do they believe that these events increase the level of crime in the city or, despite these inconveniences, they are satisfied with the organization of sporting events in their place of residence. Two, different ranks of sporting events organized in Poznan (one of the largest Polish cities and the most important sports centers in Poland) were selected for the empirical research. The first one is the Poznan Half Marathon-medium scale mass event, the second one is Cavaliada-elite international equestrian event.

\section{Research Design and Data Collection}

The authors of the presented research selected two sporting events of different sporting ranks, which took place in the city of Poznan-the capital of the Greater Poland region. The first of the surveyed events, the 6th Poznan Half Marathon, was an event in the field of mass sports, in which both amateur and professional athletes participated. The event is mainly national in nature but in recent years it has become international. It is also an event that has become a permanent feature in the sports calendar of the city of Poznan. The second surveyed event was the third edition of Cavaliada, which is an international equestrian event. The event consists of three parts: Cavaliada Sport, for top-level professionals; the Cavaliada Show, which also featured numerous amateur riders; and the Cavaliada Fair. This event has been successfully organized in the capital of Greater Poland for several years and has an international reach. The study was attended by residents of the Poznan agglomeration.

\section{Research Tool}

The method of a diagnostic survey was applied, which was the standardized interview technique with the use of the questionnaire tool during selected events. In order to carry out the research, an authorship questionnaire was prepared for the study. The division of Freyer and Gross (2002), who distinguished four types of orientation among the motives of participation in sporting events [111], was the basis for the development of the author's questionnaire survey. Based on existing literature and the results presented, it has been recognized that there is still an unexplored area in terms of the influence of non-mega sporting events on the perception of negative externalities of host residents. 
The questionnaire had 25 questions. The first part of the questionnaire focused on socio-demographic variables (Table 1). The second part of the survey focused on motives to participate in researched events. The third part of the questionnaire was designed for people who were residents of Poznan. The last part was designed for sport tourists. For the purpose of the study, we have focused only on two parts of the questionnaire (first and third).

The authors of the article received an official permission from the organizers to conduct research when the runners were finishing the race and personally filled out during the conversation with the runners. In the case of Cavaliada equestrian competition, permission was obtained only for research among fans. Authors of the article personally talked with the residents of the city: sixth Half Marathon fans and runners and Cavaliada fans. The questions examined the impact of sporting events on residents living conditions and concerned inhabitants' opinion of selected events about their negative influence of broadly understood quality of life (communication problems, noise, behavior of supporters, increase crime). The research instrument was validated before the examined event-during the 5th Poznan Half Marathon.

\section{Data Analysis}

When determining the number of recipients, information from the organizers on the expected number of participants in the event was used to make the sample selection in a way that ensured the best possible representativeness of the results obtained. The scheme of simple random sampling without replacement was used. In calculations the formula for sample size for finite population was used. The assumption was made that the maximum error of estimate (e) at 95\% confidence level should not exceed $4 \%$.

Descriptive statistics (percentages, means and standard deviations) were calculated. In order to further analyze the obtained result, respondents were asked to define the intensity level of the inconvenience associated with the organization of a sporting event in their city on a 10-point Likert scale (Table 3, Table 4, Table 5). The differences between responses were tested among the groups with a Chi-square test for independence. Statistical significance was set at $p<0.05$. When the distribution of the analyzed feature in both groups differed significantly from the normal $(p<\alpha)$, therefore the nonparametric test was used-U Mann Whitney test. All statistical analyses were conducted using Statistica Software 10.0 (StatSoft Inc., Cracow, Poland, 2011).

\section{Participants and Results of the Research}

\subsection{Socio-Demographic Characteristics of Surveyed Participants (Athletes and Supporters).}

The survey was attended by residents of Poznan: active (athletes) and passive (sports fans) participants of events. A total of 774 respondents took part in the survey: 210 Half Marathon athletes, 256 Half Marathon fans and 308 "Cavaliada" fans who were simultaneously inhabitants of the city of Poznań. There has been deliberate selection of respondents, who are participants in the event. The population questioned was chosen compared to its knowledge of the event to be able to identify simultaneously its positive and negative aspects. However, we have excluded residents who are disinterested in the event who may express a more negative outlook but who are not necessarily able to testify to the positive effects of the event. It was considered that their opinion would be objective, from the perspective of both residents and tourists. The table below present the socio-demographic profile of the respondents. A sample of 774 respondents: 315 men and 459 women participated in the event voluntarily and completed a questionnaire. The participants of the research were mainly between 18 and 25 years old (39.7\%-307) and 26-35 years old (30.7\%-238). Among the surveyed residents of Poznan, people with higher education constituted the vast majority of $41.8 \%$ (324), $27.9 \%$ (216) possessed secondary education and $18.1 \%$ (140) were people with incomplete higher education. A greater percentage of them-48.8\% (378) was professionally active and over $29.7 \%$ were students (230). The socio-demographic characteristics of respondents are presented below (Table 2). 
Table 2. Socio-demographic characteristics of surveyed participants (athletes and supporters).

\begin{tabular}{|c|c|c|c|c|c|c|c|c|}
\hline $\begin{array}{c}\text { Socio-Demographic } \\
\text { Characteristics of the } \\
\text { Respondents }\end{array}$ & \multicolumn{2}{|c|}{$\begin{array}{l}\text { Half Marathon } \\
\text { Athletes } \\
(\mathbf{N}=210)\end{array}$} & \multicolumn{2}{|c|}{$\begin{array}{l}\text { Half Marathon } \\
\text { Supporters } \\
(\mathbf{N}=256)\end{array}$} & \multicolumn{2}{|c|}{$\begin{array}{c}\text { Cavaliada } \\
\text { Supporters } \\
(\mathrm{N}=308)\end{array}$} & \multicolumn{2}{|c|}{$\begin{array}{l}\text { All Respondents } \\
(\mathbf{N}=774)\end{array}$} \\
\hline Men & 139 & 66.2 & 91 & 35.6 & 85 & 27.6 & 315 & 40.7 \\
\hline Women & 71 & 33.8 & 165 & 64.5 & 223 & 72.4 & 459 & 59.3 \\
\hline Age & $\mathrm{N}=210$ & $\%$ & $N=256$ & $\%$ & $N=308$ & $\%$ & $\mathrm{~N}=774$ & $\%$ \\
\hline $26-35$ & 93 & 44.29 & 77 & 30.1 & 68 & 22.1 & 238 & 30.7 \\
\hline $36-50$ & 20 & 9.52 & 26 & 10.2 & 39 & 12.7 & 85 & 11.0 \\
\hline $51-70$ & 3 & 1.43 & 20 & 7.8 & 6 & 1.9 & 29 & 3.7 \\
\hline 71 and more & 0 & 0.0 & 0 & 0.0 & 1 & 0.3 & 1 & 0.1 \\
\hline Education level & $\mathrm{N}=210$ & $\%$ & $N=256$ & $\%$ & $\mathrm{~N}=308$ & $\%$ & $\mathrm{~N}=774$ & $\%$ \\
\hline $\begin{array}{l}\text { Completed higher } \\
\text { education }\end{array}$ & 115 & 54.8 & 115 & 44.9 & 94 & 30.5 & 324 & 41.8 \\
\hline Employment status & $N=210$ & $\%$ & $N=256$ & $\%$ & $N=308$ & $\%$ & $\mathrm{~N}=774$ & $\%$ \\
\hline School pupil ( $<18$ years) & 16 & 7.6 & 28 & 10.6 & 88 & 28.6 & 132 & 17.0 \\
\hline Student & 62 & 29.5 & 87 & 34.4 & 81 & 26.3 & 230 & 29.7 \\
\hline Professionally active & 125 & 59.5 & 126 & 49.2 & 127 & 41.2 & 378 & 48.8 \\
\hline Unemployed & 4 & 1.9 & 12 & 4.7 & 7 & 2.3 & 23 & 3.0 \\
\hline Pensioner & 3 & 1.4 & 3 & 1.2 & 5 & 1.6 & 11 & 1.42 \\
\hline
\end{tabular}

Source: Own work on the basis of test results, $\mathrm{N}=774$.

The results of the research were divided and presented in three groups. The first two groups of results are presented in Table 3, Table 4. They contain the opinion of the participants of the 6th Poznan Half Marathon: athletes (210) and fans (256).

Table 3. Negative effects of organizing sporting events in Poznan in the opinion of residents-Half Marathon Athletes.

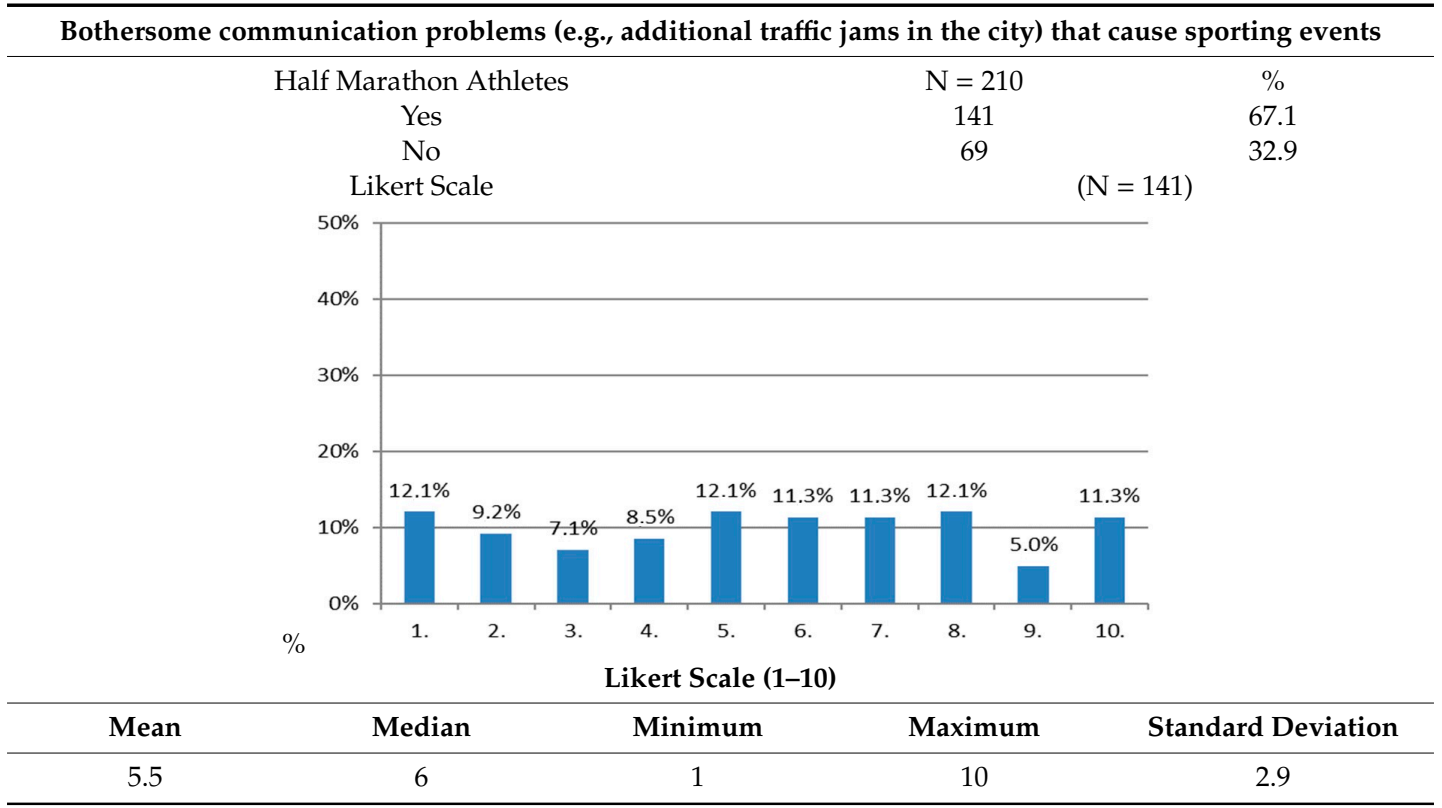


Table 3. Cont.

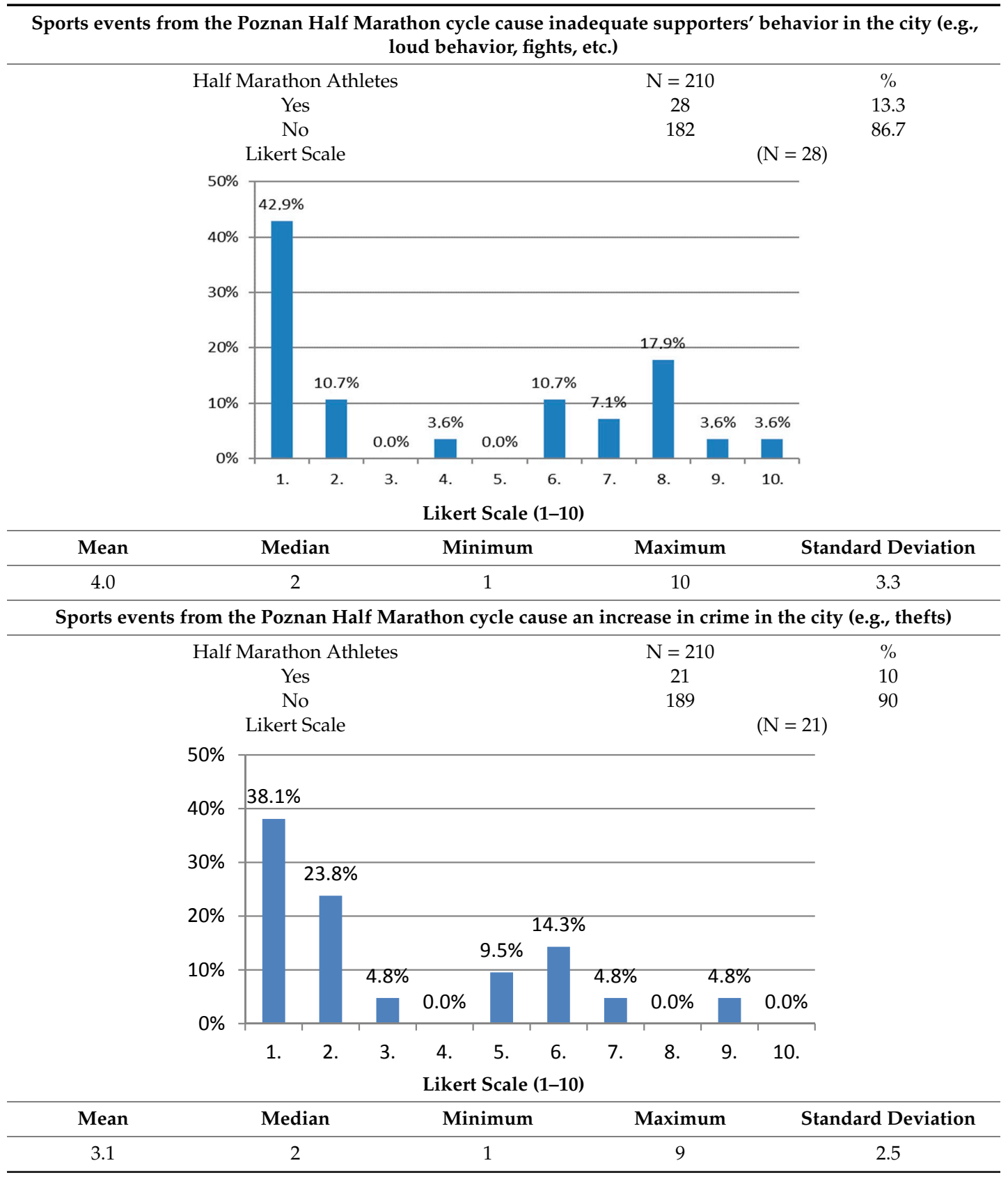


Table 3. Cont.

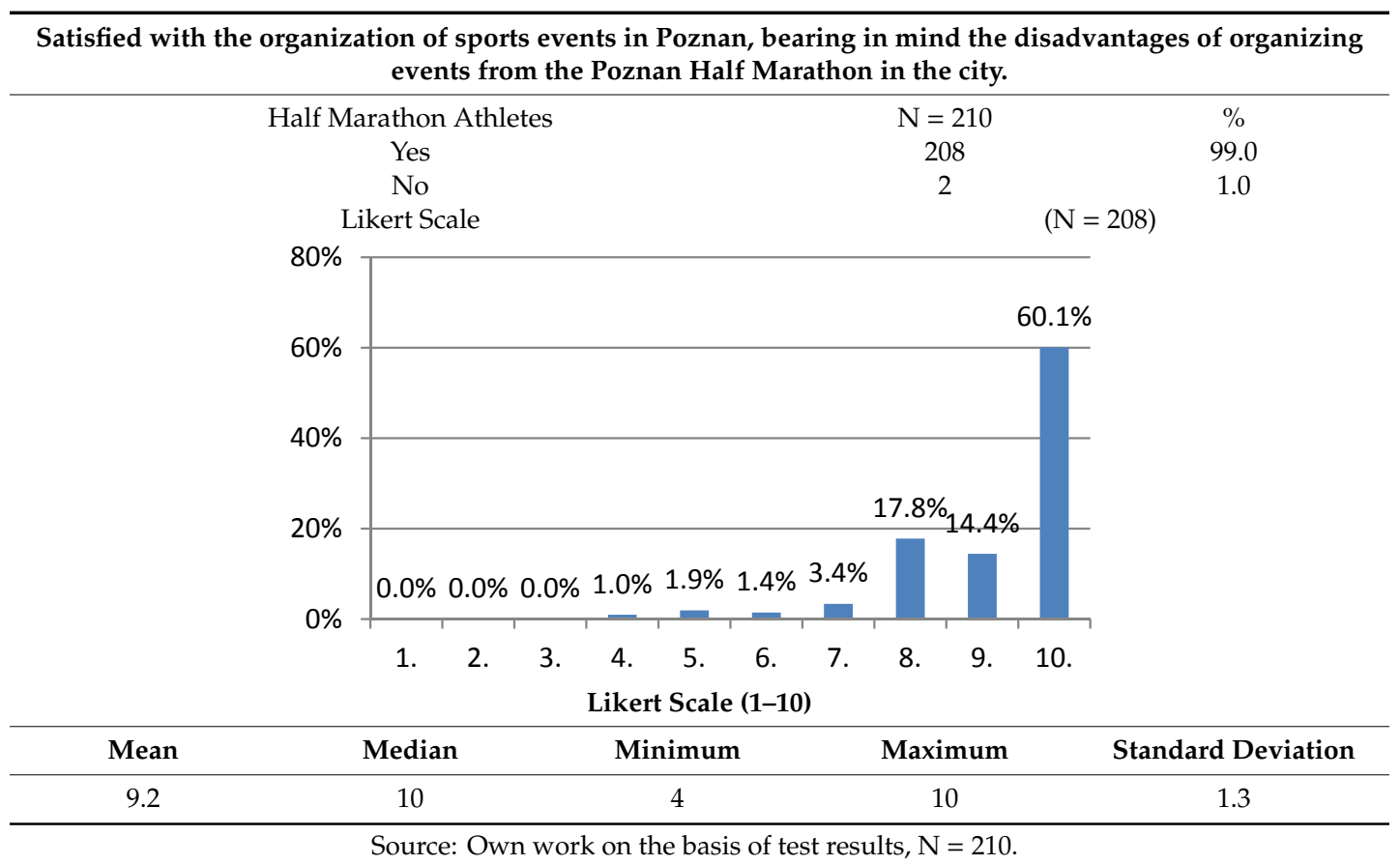

Table 4. Negative effects of organizing sporting events in Poznan in the opinion of residents-Half Marathon Fans.

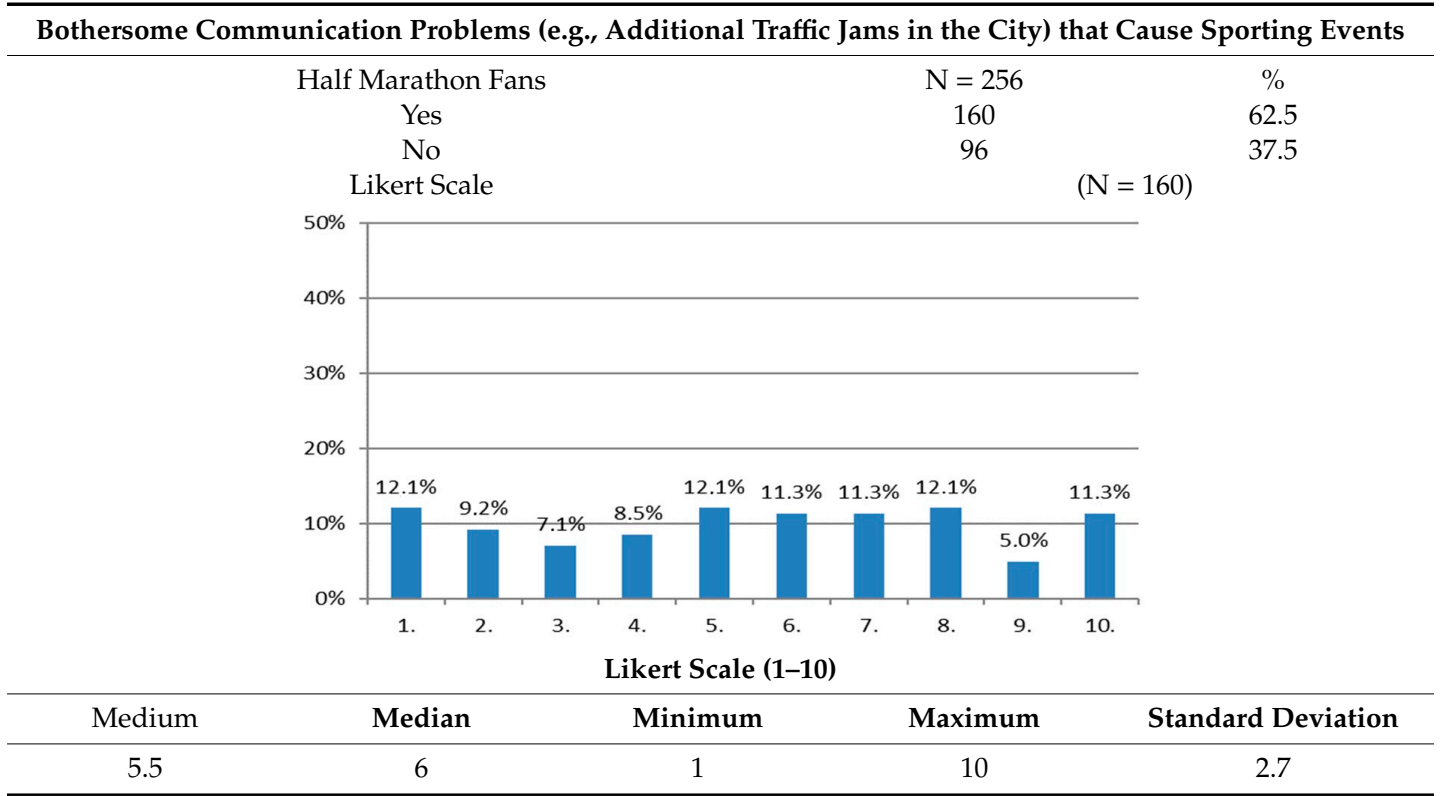


Table 4. Cont.

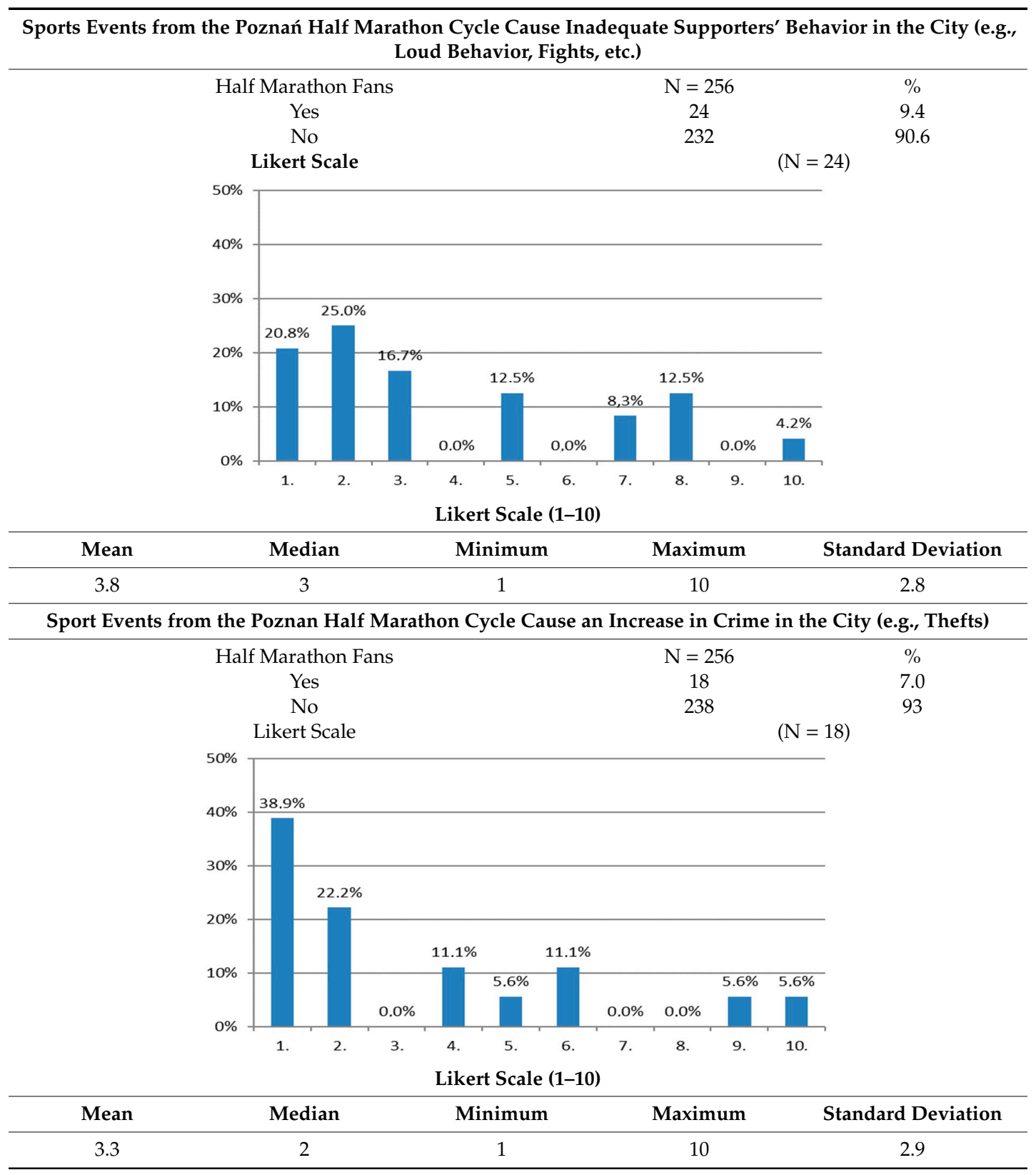


Table 4. Cont.

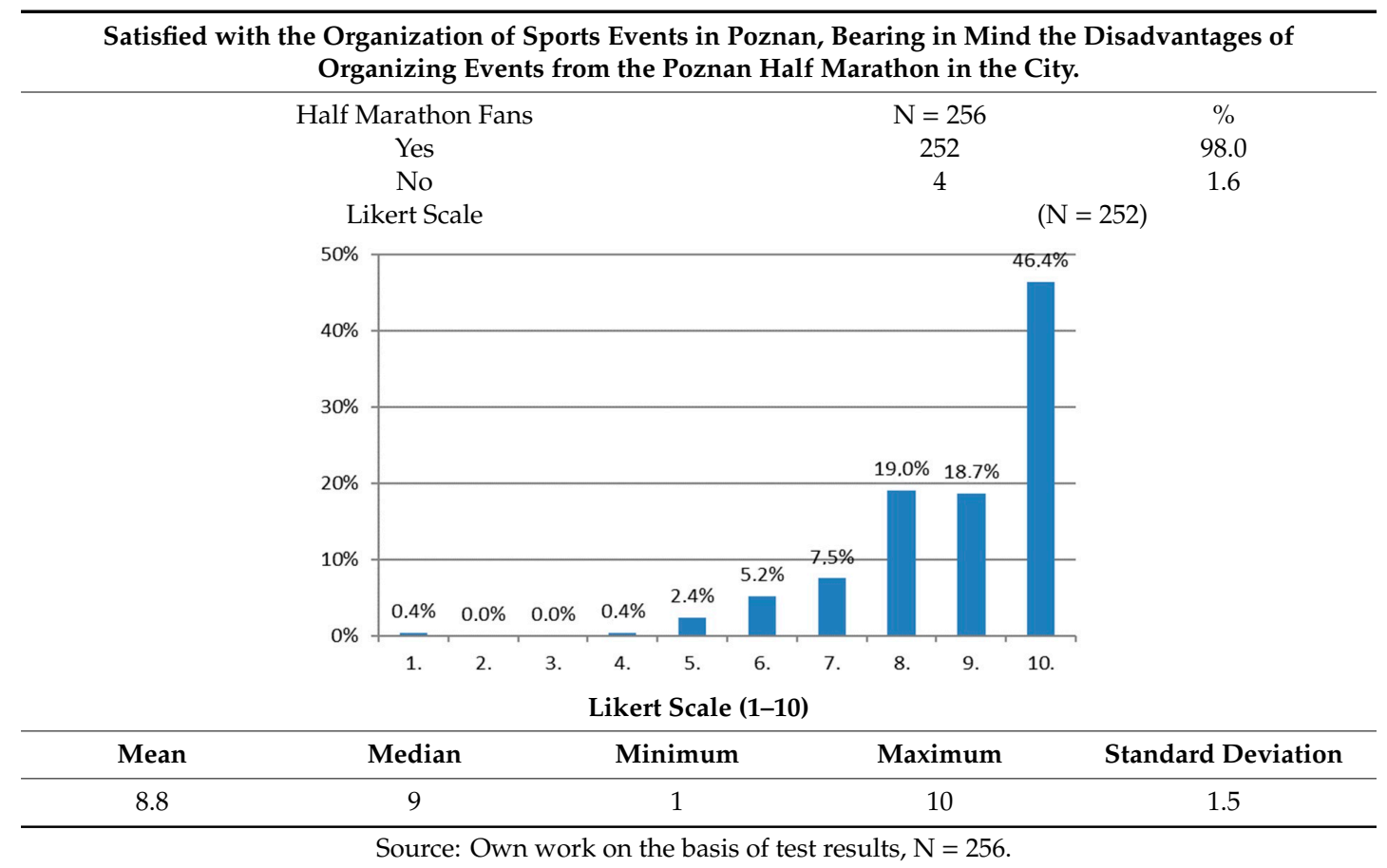

It turned out that as many as $67.1 \%$ of the athlete's respondents said that the Poznan Half Marathon causes bothersome communication problems in the city. Only $32.9 \%$ had a different opinion on this subject. In order to further analyze the obtained results, 141 respondents who said YES were asked to define the intensity level of their discomfort in the communication problems caused the 6th Poznan Half Marathon Organization on a 10-point Likert scale (answer scale: 10—very high, 1-very low). The respondents concluded that the Poznań Half Marathon causes communication problems in a city with an average level of 5.5 points.

The research has shown that more often than every tenth person $(13.3 \%-28)$ stated that the Poznan Half Marathon causes inadequate behavior of fans in the city and concluded that the Poznan Half Marathon causes inadequate supporter behavior in the city on average at 4 points on a 10-point scale. However, the majority- $86.7 \%$ had a different opinion. According to 128 participants, the fans behave properly.

Exactly every tenth person $(10 \%-21)$ said that the Poznań Half Marathon causes an increase in crime in the city. It turns out that as many as 9 out of 10 researched people had a different opinion on this subject. These 21 respondents concluded that the Poznań Half Marathon causes an increase in crime in the city on an average of 3.1 points on a 10-point scale. Moreover, as almost $99 \%$ of the surveyed residents of the Half Marathon athletes found that they were satisfied with the organization of the Poznan Half Marathon in their place of residence. Only 1\% (2 people) had a different opinion and stated that they were not satisfied with the organization of the Half Marathon in Poznan at the level of 9.2 points on a 10-point scale. It proves high social support for this sporting event among the examined group of people and even if the disadvantages are perceived by the local community-they are most likely not very onerous and short-lived (of which the respondents probably realize).

Research on the 6th Poznan Half Marathon supporters $(n=256)$ found that $62.5 \%$ said that the Half Marathon caused bothersome traffic jams in the city but 37.5\% (160) thought differently (Table 4). The supporters decided that the Half Marathon causes traffic jams in the city with an average severity of 5.5 points on a 10-point Likert scale. Moreover, less than $10 \%$ of the surveyed fans found that the Half Marathon caused inadequate behavior of the fans in the city. However, $90.6 \%$ of supporters had different opinions. The scale of inappropriate behavior of fans was estimated at 3.8 points on average $(n=24)$. 
Only $7 \%$ of surveyed fans found that the Half Marathon causes an increase in crime in the city. Most of them (93\%) had a different opinion. Fans who rated the rise in crime in the city $(n=18)$ thanks to a Half Marathon at an average of 3.3 points on a 10-point scale. The supporters' responses were almost unanimous and $98.4 \%(n=252)$ attest to their satisfaction with the organization of the Half Marathon in Poznan. Only 1.6\% (4 people) of supporters were not satisfied with this. The fans' satisfaction with the organization of the Half Marathon in Poznan were on average at the level of 8.8 points.

Authors have researched 308 Cavaliada-an international equestrian event-supporters. Studies have shown that $31.5 \%$ of them (97 people) think that the event causes onerous communication difficulties on average at 4.5 points on Likert scale (Table 5). In the case of Half Marathon fans, $62.5 \%$ of respondents answered yes (average level-5.5 points). Therefore, the Half Marathon made public transport much more difficult than Cavaliada.

Table 5. Negative effects of organizing sporting events in Poznań in the opinion of residentsCavaliada Fans.

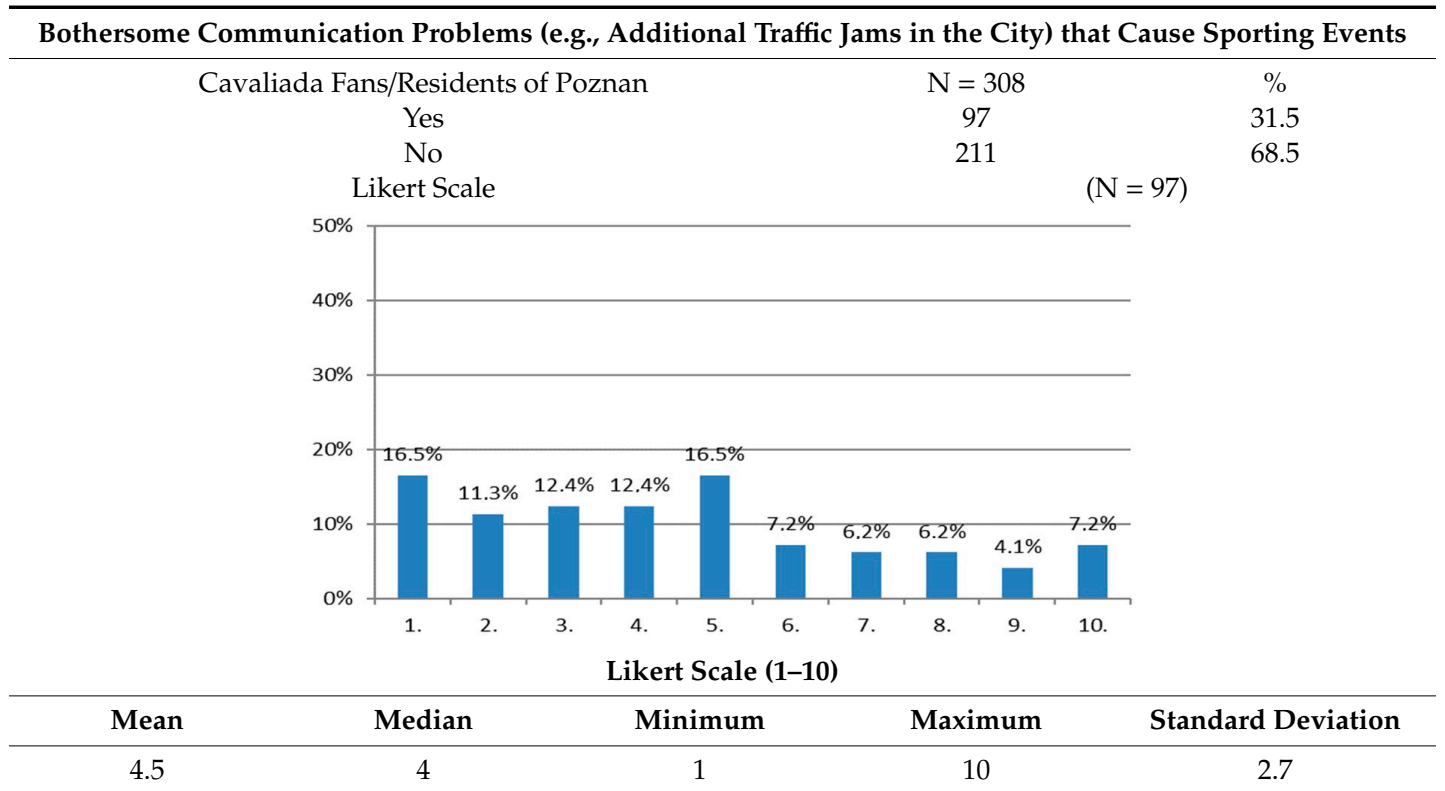




Table 5. Cont.

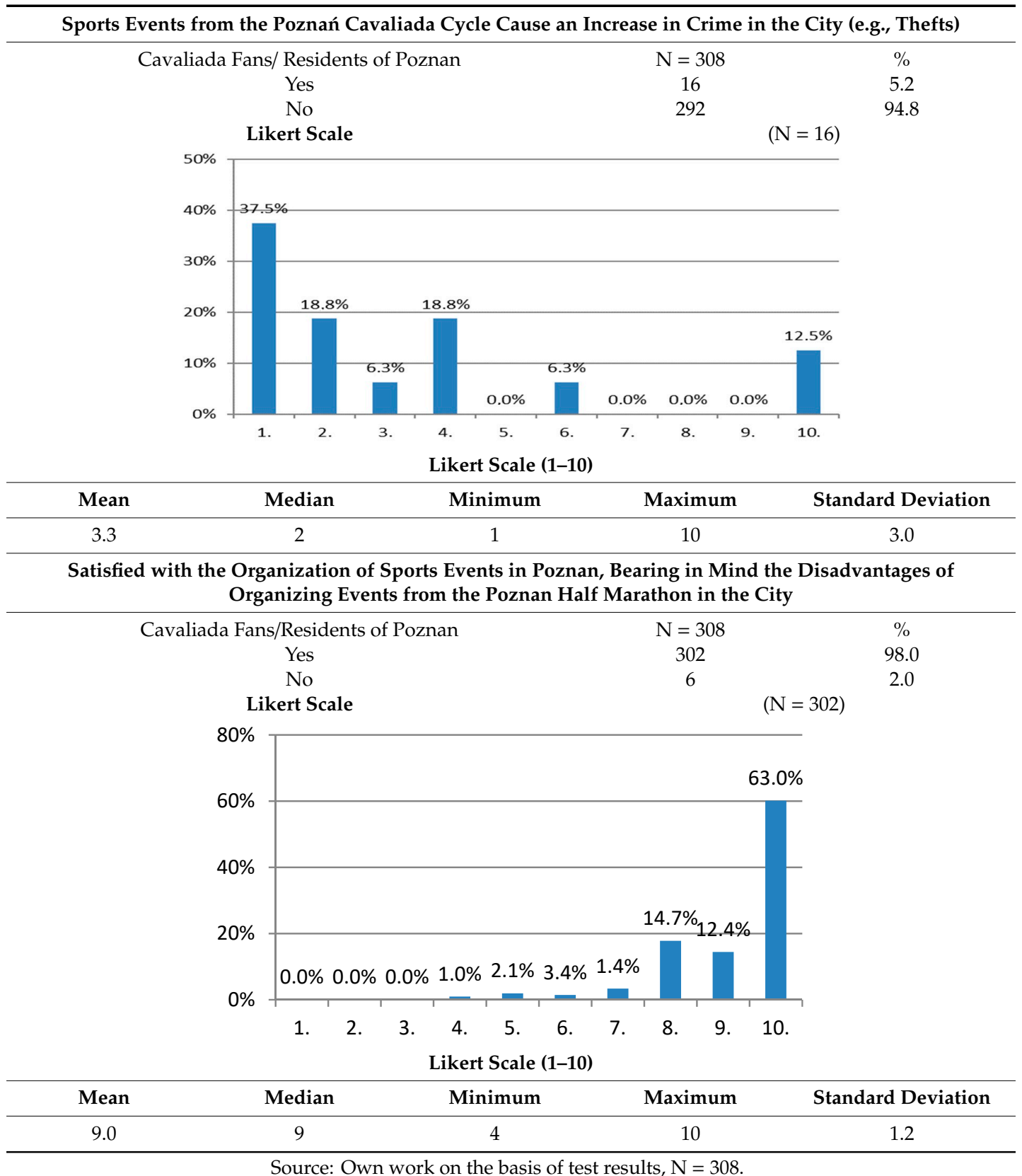

Respondents were asked a question: "Does Cavaliada cause inappropriate behavior of fans in the city (e.g., loud behavior, fights e.g.)?" and 6.2\% of them said Cavaliada caused inappropriate supporter behavior in the city (on average 4.2 points on Likert scale). In the case of the Half Marathon, $9.4 \%$ of supporters said yes. Only 5.2\% of Cavaliada fans said that this event increase in crime in the city (on average 3.3 points). In the case of the Half Marathon, $7 \%$ of supporters said yes. The supporters declared their satisfaction with the organization of the Cavaliada event in Poznan. Only 2\% (6 persons) of supporters were not satisfied with this. The fans' satisfaction with the organization of the Half Marathon in Poznan were on average at the level of 9.4 points. The fans' satisfaction with the organization of the Half Marathon in Poznan were on average at the level of 8.8 points.

From the point of view of the conducted analysis, it proved important to check the difference between the two examined groups of respondents: Half Marathon fans and Cavaliada fans, among those who answered YES - the average level of dissatisfaction significantly different between the 
analyzed groups (Likert scale 1-10). For this purpose, Chi-square test and U Mann Whitney's test was used:

\subsection{Bothersome Communication Problems (e.g., Additional Traffic Jams in the City) that Cause Sporting Events}

Checking if the fractions of the people who answered YES to this question differ significantly between the two analyzed groups-Chi-square test. Fractions differ from each other in a statistically significant way: $p$-value $=0.000(<0.05)$. There is a relationship between the type of event and the answer to the question being analyzed. The distribution of the analyzed feature in both groups differs significantly from the normal $(p<\alpha)$, therefore the nonparametric test was used-U Mann Whitney test. The average level of dissatisfaction differs significantly between the analyzed groups: $p=0.004$ (the average in the samples was: for the Half Marathon 5.53, for Cavaliada-4.54). For the one-sided test: $p=0.004 / 2=0.002$. Then it can be assumed that the participants of the Half Marathon have an average level of dissatisfaction higher than the average level of dissatisfaction of Cavaliada participants.

\subsection{Sports Events from the Poznan Half Marathon Cycle Cause Inadequate Supporters' Behavior in the City} (e.g., Loud Behavior, Fights, etc.)

Checking if the fractions of the people who answered YES to this question differ significantly between the two analyzed groups-Chi-square test. Chi-square test. Fractions do not differ from each other in a statistically significant way: $p$-value $=0.153(>0.05)$. It cannot be assumed that there is a relationship between the type of event and the answer to the question being analyzed. The distribution of the analyzed feature in both groups again differs significantly from the normal $(p<\alpha)$, therefore the nonparametric test was be used-U Mann Whitney's test. The average level of dissatisfaction is not significantly different between the analyzed groups $p=0.990$ (the average in the samples was, for the Half Marathon 3.83, for Cavaliada 4.16)

\subsection{Sports Events from the Poznan Half Marathon Cycle Cause an Increase in Crime in the City (e.g., Thefts)}

Checking if the fractions of the people who answered YES to this question differ significantly between the two analyzed groups-Chi-square test. Fractions do not differ from each other in a statistically significant way: $p$-value $=0.362(>0.05)$. It cannot be assumed that there is a relationship between the type of event and the answer to the question being analyzed. The distribution of the analyzed feature in both groups again differs significantly from the normal $(p<\alpha)$, therefore the nonparametric test was used-U Mann Whitney's test. The average level of dissatisfaction is not significantly different between the analyzed groups $p=0.971$ (the average in the samples was: for the Half Marathon 3.28, for Cavaliada - 3.31).

\subsection{Satisfied with the Organization of Sports Events in Poznan, Bearing in Mind the Disadvantages of Organizing Events from the Poznan Half Marathon in the City}

Checking if the fractions of the people who answered YES to this question differ significantly between the two analyzed groups-Chi-square test. Fractions do not differ from each other in a statistically significant way: $p$-value $=0.730(>0.05)$. It cannot be assumed that there is a relationship between the type of event and the answer to the question being analyzed. The distribution of the analyzed feature in both groups again differs significantly from the normal $(p<\alpha)$, therefore the nonparametric test was used-U Mann Whitney's test. The average level of satisfaction differs significantly between the analyzed groups: $p=0.000$ (the average in the samples was: 8.82 for the Half Marathon, 9.25 for Cavaliada). For the one-sided test: $p=0.000 / 2=0.000$. Then it can be assumed that the participants of the Half Marathon have an average level of satisfaction significantly lower than the average level of satisfaction of Cavaliada participants. 


\section{Discussion}

A review of the literature on the problem shows that there is little research on the impact of small sporting events on the quality of life of residents. In addition, studies on the relationship between mega sporting events and the place where they are organized have a relatively short history and the first studies appeared after 1984 under the influence of LIO in Los Angeles [108,109]. Over the next 30 years, there were research results showing the relationship between events and their host [23,111-114]. In Poland, the first such research and reports began in 2007 when the results of the selection of the host of Euro 2012 was announced [115]. This gave impetus to get interested in the subject. There were few studies that referred to economic [115-119], tourists [24,120,121] and sociological [122] issues. All these studies refer to the analysis of the relationship between a sporting event and the place where it takes place and includes the effect, impact and influence of the mega event on the host [121]. Street running has already been analyzed from the side of runners' profiles and their motivation to participate in events $[90,91,123]$. Moreover, it was emphasized that the venue for the organization of running is increasingly important for sustainable development. For example, the effects of organizing running events in national parks were researched $[96,97,124]$. The impact of running events on local communities in the context of health promotion was also examined [100] but the results of the research on the negative impact of running events on the urban community have not been met before in the literature. There are not so many studies that concern small and local events and their negative or positive impact on residents $[22,105,125,126]$. Many authors at that time took up the issue of sports tourism, which is related to the organization of sporting events [107,127-130]. Sports tourism, if well organized, has the potential of creating more positive economic, social and cultural benefits to the host community. This is a kind of tourism that has recently been used to enhance the city's identity and appeal to businesses and travelers. Most cities' bids to host sporting events in order to achieve urban regeneration with revenues being generated from TV licenses and other areas. However, cities also face difficulties while trying to assess the impacts of these events when set against the costs incurred. This applies to the organization of major sporting events in popular tourist destinations. That is why many authors dealt with issues in this area, especially social impacts of hosting major sport events. Kim and co-authors [25] were trying to develop a complex scale to evaluate the perceived six social impacts of a large-scale sport tourism event. There were economic benefits; community pride; community development; economic costs; traffic problems; and security risks. Their questionnaire was tested among community of host's residents for the Formula One Korean Grand Prix in South Korea. They wanted to understand how residents view the impacts of a large sporting tourism event [25]. Liu, using Shanghai Formula One as a case study, examine the impact of mega sporting events on host city image from the international students perspective [131]. Leisure facilities and service were the most positive image impact in the opinion of the respondents. International students disagreed that Formula One would result in security problems or any crime. They had doubts about any negative impact on their daily life or environment. Lunhua \& Haiyan [132] investigated residents' perceptions of the social impact of the Formula One Chinese Grand Prix and examined the relationships between the perceptions of social impact and four sets of variables. The results showed one dimension of negative impact (environmental and cultural problems) which was significantly associated with involvement in sports industry, community attachment and identification with the event. Moreover, Liu [133] developed a scale to measure the legacy of psychic income associated with the Olympic Games. The research collected from Beijing residents during the 2008 Beijing Games, identified a seven-factor of a scale of measuring psychic income (SPI) with 24 pertinent items retained. A study conducted by Balduck et al. [134] contributes to this line of inquiry by assessing the impact of the arrival of a stage of the 2007 Tour de France in Ghent. Exploratory factor analysis revealed seven impact factors. The most highly perceived benefits were cultural and image benefits whereas the most highly perceived costs were excessive spending and mobility problems. But Yi-De Liu [26] wrote that improving residents' quality of life (QoL) is one main reason to host major events. Also, event legacy has been emerging as a key outcome associated with the hosting of an event. Based on a case study of 
Liverpool as the 2008 European Capital of Culture (ECOC), the research indicate that the most highly perceived benefits were image, identity and cultural legacies. However, respondents were less likely to perceive the legacy of economic and tourism development on their QoL. The study underlines also the importance of legacy planning as a holistic program from the early stages of event process [26].

However, presented examples of conducted research concern large sporting events and show that no one studied the impact of the organization of less known, medium scale sporting events on residents on the perception of negative externalities by host residents. The authors of the present paper did not reach the results of the research, which would show an assessment of the impact of the organization of non-mega scale sports events on the quality of the hosts' lives. With reference to the Faulkner and Tideswell studies [135], the perceptions of community members are important and, furthermore, obtaining responses from a diverse group of residents is essential in representing the varied perceptions. For example, Bynner [136] stated that longitudinal data is needed to study the transition process involved, the effects of societal change and the policy impact.

\section{Final Conclusions}

The theoretical part of this article presents the meaning of sporting events for tourism industry and indicates the negative and positive effects this kind of tourism brings to host cities. The whole refers to the theoretical foundations of the term of "overtourism." The second part presents results of empirical research was conducted by the method of diagnostic surveys during two sporting events of different sporting rank, which took place in Poland and represented various sports disciplines-running and horse riding. The case study is the city of Poznan and two, well-known events in this agglomeration. The first one is Poznan Half Marathon-mass sports event, the second one is Cavaliada-elite equestrian event. A total of 774 respondents took part in the study, resident hosts who took part in the studied events. The main goal of this study was to investigate the impact of non-mega sporting events on quality of the host's life. The detailed aim of the study was to examine whether the inhabitants of the city feel the negative effects of organizing sporting events (communication problems or inappropriate behavior of supporters) and do they believe that these events increase the level of crime in the city or, despite these inconveniences, they are satisfied with the organization of sporting events in their place of residence. This phenomenon can also be referred to the social exchange theory (SET) to analyze the perceptions of residents. Many authors [135,137-139] have continuously drawn on this theory. For example, Homans [137], the author of SET has been applied it to variety of leisure disciplines, to understand the views of local residents with regard to tourism. Harrill [139] states that SET involves the trading and sharing of resources between individuals and groups. Ap [140] things that not only highlights the exchange of resources but has also been expanded to include the mutual benefits that all exchange participants can get. In applying this to tourism, research by Teye et al. [141] indicates that perceived benefits associated with host community improvement led to support of residents. Moreover, Waitt [142] has found that enthusiasm of the residents and support varied according to how tourism events were perceived either positively according to the benefits derived or negatively with respect to any costs incurred from what they supplied. It is essential that event organizers and affiliates consider the local voices about the sport tourism event.

The results of the presented research show that both athletes as well as fans of the Half Marathon said that the Poznan Half Marathon causes bothersome communication problems in the city. Cavaliada, as an international equestrian event, causes onerous communication difficulties only in the opinion of $31.5 \%$ of researched respondents. Therefore, the Half Marathon made public transport much more difficult than Cavaliada situated in one place-Poznan Trade Centre. It also turned out that in the opinion of most of the researched fans and athletes, the surveyed events did not cause inadequate behavior of fans in the city or an increase in crime in the city and people are satisfied with the organization of these events. It turns out that the inhabitants, despite minor inconveniences that are felt as a result of organizing sporting events in the city, must also see the benefits. The negative impact of Cavaliada was very low. For checking the difference between the two examined groups of 
respondents: Half Marathon fans and Cavaliada fans, Chi-square test and Mann Whitney's test was used. The participants feel bothersome communication problems that cause the Half Marathon and have an average level of dissatisfaction higher than the average level of dissatisfaction of Cavaliada participants. Moreover, the participants of the half marathon have an average level of satisfaction with the organization of sports events in Poznan significantly lower than the average level of satisfaction of Cavaliada participants. Therefore, an elite sporting event is less burdensome for its residents and gives them more satisfaction. They do not think the event will harm them. However, they are aware of social exchange and profits for the city. The conclusions and reflections resulting from these studies can be used by organizers of non-sporting events and be their inspiration. Importantly, the inhabitants play an important role in the development of sustainable tourism, because they are cultural agents and the social group in which tourism is provided and local hospitality is a key element of the tourism product [143].

The paper provides data that may be useful for support marketing events such as half marathons. The popularity of sporting events participation fulfills a number of important sociocultural functions in the modern world. The most important include enabling sports tourists to build a sense of connection and integration with other people, thanks to which sports events become a postmodern form of participation in social life. Further research should go towards recognizing the importance and impact of small sporting events on people's lives and their environment. These types of events are definitely less recognized but their growing popularity indicates great importance for the development of cities and regions, tourism and economics.

Author Contributions: Conceptualization, E.M.-M.; methodology, E.M.-M.; software, J.P.; validation, E.M.-M.; formal analysis, J.P., E.M.-M.; investigation, E.M.-M.; resources, J.P., E.M.-M., A.D., M.K., F.G.; data curation, J.P., E.M.-M.; writing—original draft preparation, J.P.; writing—review and editing, J.P.; visualization, J.P.; supervision, E.M.-M., J.P.; project administration, J.P., E.M.-M. All authors have read and agreed to the published version of the manuscript.

Funding: This research received no external funding.

Conflicts of Interest: The authors declare no conflict of interest.

\section{References}

1. Weed, M.; Bull, C. Sport Tourism: Participants, Policy and Providers; Elsevier Butterworth Heinemann: Oxford, UK, 2009.

2. Klaus, P.; Maklan, S. Bridging the gap for destination extreme sports-A model of sports tourism customer experience. J. Mar. Man. 2011, 27, 1341-1365. [CrossRef]

3. Scolozzi, R.; Schirpke, U.; Detassis, C.; Abdullah, S.; Gretter, A. Mapping alpine landscape values and related threats as perceived by tourists. Lands. Res. 2015, 40, 451-465. [CrossRef]

4. Bastian, O.; Stein, C.; Lupp, G.; Behrens, J.; Renner, C.; Grunewald, K. The appreciation of nature and landscape by tourism service providers and visitors in the Ore Mountains (Germany). Lands. On. 2015, 41, 1-23. [CrossRef]

5. Shi, L.; Zhao, H.; Li, Y.; Ma, H.; Yang, S.; Wang, H. Evaluation of Shangri-La County's tourism resources and ecotourism carrying capacity. Int. J. Sust. Dev. World Ecol. 2015, 22, 103-109. [CrossRef]

6. Navarro Jurado, E.; Tejada Tejada, M.; Almeida García, F.; Cabello González, J.; Cortés Macías, R.; Delgado Peña, J.; Fernández Gutiérrez, F.; Gutiérrez Fernández, G.; Luque Gallego, M.; Málvarez García, G.; et al. Carrying capacity assessment for tourist destinations: Methodology for the creation of synthetic indicators applied in a coastal area. Tour. Manag. 2012, 33, 1337-1346. [CrossRef]

7. Ali, R. Foreword: The coming perils of overtourism. In Icelands and Trails of 21st Century Overtourism. A Deep Dive into Destinations; Rafat, A., Clampet, J., Eds.; Skift: New York, NY, USA, 2016; Available online: https://skift.com/iceland-tourism/ (accessed on 9 September 2019).

8. UNWTO (United Nations World Tourism Organisation). Overtourism: Understanding and Managing Urban. Tourism Growth Beyond Perceptions; UNWTO: Madrid, Spain, 2018. 
9. WTTC \& McKinsey \& Company (Producer). Coping with Success: Managing Overcrowding in Tourism Destinations. Available online: https:/www.wttc.org/priorities/sustainable-growth/destinationstewardship/ (accessed on 24 September 2019).

10. Postma, A.; Papp, B.; Koens, K. Visitor Pressure and Events in an Urban. Setting. Understanding and Managing Visitor Pressure in Seven European Urban. Tourism Destinations; Centre of Expertise Leisure, Tourism \& Hospitality CELTH: Breda, The Netherlands, 2018.

11. Kušcer, K.; Mihalic, T. Residents' Attitudes towards Overtourism from the Perspective of Tourism Impacts and Cooperation-The Case of Ljubljana. Sustainability 2019, 11, 1823. [CrossRef]

12. Muler González, V.; Galí Espelt, N.; Coromina Soler, L. Overtourism: Residents' perceptions of tourism impact as an indicator of resident social carrying capacity-Case study of a Spanish heritage town. Tour. Rev. 2018, 73, 277-296. [CrossRef]

13. Koens, K.; Postma, A.; Papp, B. Is Overtourism Overused? Understanding the Impact of Tourism in a City Context. Sustainability 2018, 10, 4384. [CrossRef]

14. Pappalepore, I.; Maitland, R.; Smith, A. Prosuming creative urban areas. Evidence from East London. Ann. Tour. Res. 2014, 44, 227-240. [CrossRef]

15. Koens, K.; Thomas, R. "You know that's a rip-off": Policies and practices surrounding micro-enterprises and poverty alleviation in South African township tourism. J. Sustain. Tour. 2016, 24, 1641-1654. [CrossRef]

16. Goodwin, H. The Challenge of Overtourism, Responsible Tourism Partnership Working Paper 4. October 2017. Available online: https://haroldgoodwin.info/pubs/RTP\%27WP4Overtourism01\%272017.pdf (accessed on 21 September 2019).

17. Peeters, P.; Gössling, S.; Klijs, J.; Milano, C.; Novelli, M.; Dijkmans, C.; Eijgelaar, E.; Hartman, S.; Heslinga, J.; Isaac, R.; et al. Research for TRAN Committee-Overtourism: Impact and Possible Policy Responses, European Parliament, Policy Department for Structural and Cohesion Policies, Brussels. 2018. Available online: http://www.europarl.europa.eu/thinktank/en/document.html?reference=IPOL_STU(2018)629,184 (accessed on 12 September 2019).

18. Hautbois, C.; Djaballah, M.; Desbordes, M. The social impact of participative sporting events: A cluster analysis of marathon participants based on perceived benefits. Sport Soc. 2019, 23, 335-353. [CrossRef]

19. Hall, C. Adventure, Sport and Health Tourism. In Special Interest Tourism; Weiler, B., Hall, C., Eds.; Belhaven Press: London, UK, 1992; pp. 141-158.

20. Hallmann, K.; Breur, C. Image Fit between Sport Events and their Hosting Destinations from an Active Sport Tourist Perspective and its Impact on Future Behaviour. J. Sport Tour. 2010, 15, 215-237. [CrossRef]

21. Barclay, J. Predicting the Costs and Benefits of Mega-Sporting Events: Misjudgement of Olympic Proportions? Inst. Econ. Aff. 2009, 29, 62-66. [CrossRef]

22. Taks, M. Social sustainability of non-mega sport events in a global world. Eur. J. Sport Soc. 2013, 10, $121-141$. [CrossRef]

23. Lee, C.K.; Taylor, T. Critical reflections on the economic impact assessment of a mega-event: The case of 2002 FIFA World Cup. Tour. Manag. 2005, 26, 595-603. [CrossRef]

24. Preuss, H. Aspects of Olympic Games Tourism. 2007. Available online: www.sete.gr (accessed on 12 October 2019).

25. Kim, W.; Jun, H.M.; Walker, M.; Drane, D. Evaluating the perceived social impacts of hostinghosting large-scale sport tourism events: Scale development and validation. Tour. Manag. 2015, 48, 21-32. [CrossRef]

26. Liu, Y.-D. Quality of Life as Event Legacy: An Evaluation of Liverpool as the 2008 European Capital of Culture. Appl. Res. Qual. Life 2017, 12, 653-670. [CrossRef]

27. Kim, H.J.; Gursoy, D.; Lee, S. The impact of the 2002 World Cup on South Korea: Comparisons of pre- and post-games. Tour. Man. 2006, 27, 86-96. [CrossRef]

28. Kim, S.S.; Petrick, J.F. Residents' perceptions on impacts of the FIFA 2002 World Cup: The case of Seoul as a host city. Tour. Man. 2005, 26, 25-38. [CrossRef]

29. Ohmann, S.; Jones, I.; Wilkes, K. The perceived social impacts of the 2006 Football World Cup on Munich residents. J. Sp. Tour. 2006, 11, 129-152. [CrossRef]

30. Jönsson, C.; Lewis, C.C. Impacts of Hosting a Sport Event in Tourism High Season, RASAALA. Play Time Sports 2014, 5, 1-17. Available online: https:/www.researchgate.net/publication/267525172_Impacts_of_ Hosting_a_Sport_Event_in_Tourism_High_Season (accessed on 12 September 2019).

31. Glyptis, S. Sport and Tourism in Western Europe; British Travel Education Trust: London, UK, 1982. 
32. Gammon, S.; Robinson, T. Sport and tourism: A conceptual framework. J. Sport Tour. 1997, 4, 11-18. [CrossRef]

33. Gibson, H. Sport tourism: A critical analysis of research. Sport Manag. Rev. 1998, 1, 45-76. [CrossRef]

34. Perić, M.; Vitezić, V.; Mekinc, J. Active event sport tourism experience: The role of the natural environment, safety and security in event business models. Int. J. Sus. Dev. Plann. 2018, 13, 758-772. [CrossRef]

35. Hall, C. Adventure, Sport and Health Tourism. In Special Interest Tourism; Weiler, B., Hall, C., Eds.; Bellhaven: Londyn, UK, 1992.

36. Kurtzman, J.; Zauhar, J. A wave in time-The sports tourism Phenomena. J. Sport Tour. 1997, 4, 7-24. [CrossRef]

37. Prahalad, C.K.; Ramaswamy, V. Co-creation experiences: The next practice in value creation. J. Interact. Mark. 2004, 18, 5-14. [CrossRef]

38. Perić, M.; Vitezić, V.; Mekinc, J. Conceptualising innovative business models for sustainable sport tourism. Int. J. Sustain. Dev. Plan. 2016, 11, 469-482. [CrossRef]

39. Higham, J. Sport Tourism as an Attraction for Managing Seasonality. Sport Soc. Cul. Com. Med. Pol. 2005, 8, 238-262. [CrossRef]

40. Yeoman, I.; Napier, M.R.; Ali-Knight, J.; Drummond, S.; McMahon-Beattie, U. Introduction. In Festival and Event Management, An International Arts and Culture Perspective; Yeoman, I., Robertson, M., Ali-Knight, J., Drummond, S., McMahon-Beattie, U., Eds.; Elsevier Butterworth-Heinemann: Oxford, UK, 2004; pp. $19-21$.

41. Perić, M.; Vitezić, V.; Mekinc, J. Comparing Business Models for Event Sport Tourism: Case Studies in Italy and Slovenia. Event Manag. 2019, 23, 379-397. [CrossRef]

42. Russo, A.P.; Scarnato, A. “Barcelona in common": A new urban regime for the 21st-century tourist city? J. Urban Aff. 2018, 40, 455-474. [CrossRef]

43. Dwyer, L. Relevance of triple bottom line reporting to achievement of sustainable tourism: A scoping study. Tour. Rev. Int. 2005, 9, 79-93. [CrossRef]

44. Hede, A.M. Managing Special Events in the New Era of the Triple Bottom Line. Event Manag. 2007, 11, 13-22. [CrossRef]

45. Ahmed, T.S.A.A. A triple bottom line analysis of the impacts of the Hail International Rally in Saudi Arabia. Manag. Sport Leis. 2017, 22, 276-309. [CrossRef]

46. Lee, S.; Krohn, B.D. A study of psychological support from local residents for hosting megasporting events: A case of the 2012 Indianapolis Super Bowl XLVI. Event Manag. 2013, 17, 361-376. [CrossRef]

47. Preuss, H.; Solberg, H.A. Attracting major sporting events: The role of local residents. Eur. Sport Manag. Q. 2006, 6, 391-411. [CrossRef]

48. Hritz, N.; Ross, C. The Perceived Impacts of Sport Tourism: An Urban Host Community Perspective. J. Sport Manag. 2010, 24, 119-138. [CrossRef]

49. Perić, M.; Đurkin, J.; Wise, W. Leveraging Small-Scale Sport Events: Challenges of Organising, Delivering and Managing Sustainable Outcomes in Rural Communities, the Case of Gorski kotar, Croatia. Sustainability 2016, 8, 1337. [CrossRef]

50. Wise, N. Outlining Triple Bottom Line Contexts in Urban Tourism Regeneration. Cities 2016, 53, 30-34. [CrossRef]

51. Getz, D. Event tourism: Definition, evolution and research. Tour. Manag. 2008, 29, 403-428. [CrossRef]

52. Getz, D.; Pageis, S.J. Progress and prospects for event tourism research. Tour. Manag. 2016, 52, 593-631. [CrossRef]

53. Peric, M.; Vitezic, V. Socio-Economic Impacts of Event Failure: The Case of a Cancelled International Cycling Race. Sustainability 2019, 11, 5028. [CrossRef]

54. Chalip, L. From legacy to leverage. In Leveraging Legacies from Sports Mega-Events: Concepts and Cases; Grix, J., Ed.; Palgrave Macmillan: London, UK, 2014; pp. 2-12.

55. Fairley, S.; Lovegrove, H.; Brown, M. Leveraging events to ensure enduring benefits: The legacy strategy of the 2015 AFC, Asian Cup. Sport Manag. Rev. 2016, 19, 466-474. [CrossRef]

56. Schnitzer, M.; Schlemmer, P.; Kristiansen, E. Youth multi-sport events in Austria: Tourism strategy or just a coincidence? J. Sport Tour. 2017, 21, 179-199. [CrossRef]

57. Deccio, C.; Baloglu, S. Nonhost community resident reactions to the 2002Winter Olympics: The spillover impacts. J. Travel Res. 2002, 41, 46-56. [CrossRef] 
58. Toohey, K.; Taylor, T. Mega Events, Fear and Risk: Terrorism at the Olympic Games. J. Sport Manag. 2008, 22, 451-469. [CrossRef]

59. Konstantaki, M.; Wickens, E. Residents' perception of environmental and security issues at the 2012 London Olympic Games. J. Sport Tour. 2010, 15, 337-357. [CrossRef]

60. Prayag, G.; Hosany, S.; Nunkoo, R.; Alderset, T. London residents' support for the 2012 Olympic Games: The mediating effect of overall attitude. Tour. Manag. 2013, 36, 629-640. [CrossRef]

61. Reis, A.C.; Frawley, S.; Hodgetts, D.; Thompson, A.; Hughs, K. Sport Participation Legacy and the Olympic Games: The Case of Sydney 2000, London 2012 and Rio 2016. Event Manag. 2017, 21, 139-158. [CrossRef]

62. Liu, D.; Hautbois, C.; Desbordes, M. The expected social impact of the Winter Olympic Games and the attitudes of non-host residents toward bidding: The Beijing 2022 bid case study. Int. J. Sports Market. Spon. 2017, 18, 330-346, ISSN: 1464-6668. [CrossRef]

63. Cheung, S.Y.; Mak, J.Y.; Dixon, A.W. Elite active sport tourists: Economic impacts and perceptions of destination image. Event Manag. 2016, 20, 99-108. [CrossRef]

64. Machrowicz-Mośko, E. Turystyka Sportowa, Akademia Wychowania Fizycznego im. Eugeniusza Piaseckiego w Poznaniu, 2018, 208 s. Seria: Podręczniki nr 79/Sport Tourism; Series: Textbooks No. 79; University of Physical Education in Poznan: Poznań, Poland, 2018; Volume 208, ISBN: 978-83-64747-19-9.

65. Jamieson, N. Sport tourism events as community builders-How social capital helps the "locals" Cope. J. Conv. Event Tour. 2014, 15, 57-68. [CrossRef]

66. Gibson, H.J.; Walker, M.; Thapa, B.; Kaplanidou, K.; Geldenhuys, S.; Coetzee, W. Psychic income andsocial capital among host nation residents: A prepost analysis of the 2010 FIFA World Cup in South Africa. Tour. Manag. 2014, 44, 113-122. [CrossRef]

67. Duran, P. The Impact of the Games on Tourism: Barcelona: The Legacy of the Games, 1992-2002; Centre d'Estudis Olímpics UAB: Barcelona, Spain, 2005; Available online: http://olympicstudies.uab.es/pdf/wp083.pd (accessed on 15 September 2019).

68. Paise for Barcelona's Olympic Legacy as City IOC's Olympic Solidarity Commission 25 Years on from the Games. Available online: https://www.olympic.org/news/praise-for-barcelona-s-olympic-legacy-as-city-welcomes-iocs-olympic-solidarity-commission-25-years-on-from-the-games (accessed on 10 September 2019).

69. Law, C.M. Urban. Tourism, Attracting Visitors to Large Cities; Patronat de Turisme (1993): Memoria 1992; Patronat de Turisme, Ajuntament de Barcelona: Barcelona, Spain, 1993; Continuum International Publishing Group: New York, NY, USA, 1994.

70. Brunet, F. An economic analysis of the Barcelona '92 Olympic Games: Resources, financing and impact. In The Keys to Success; Demogaras, M., Botella, M., Eds.; Centre d'Estudis Olimpics de l'Esport, Universitat Autonoma de Barcelona: Barcelona, Spain, 1995.

71. Truno, E. Barcelona: City of sport. In The Keys to Success; Ref. WP083; De Mogaras, M., Botella, M., Eds.; Centre d'Estudis Olimpics i de l'Esport, Universitat Autonoma de Barcelona, Ajuntament de Barcelona: Barcelona, Spain, 1995.

72. Truño, E. Barcelona: City of sport. In Miquel de Moragas \& Miquel Botella, The Keys to Success: The Social, Sporting, Economic and Communications Impact of Barcelona'92; Servei de Publicacions de la UAB: Barcelona, Spain, 2005; pp. 43-56.

73. Van der, B.; Braun, L.E.; Otgaar, A.H.J. Sports and City Marketing in European Cities. Rotterdam: Euricur; European Institute for Comparative Urban Research: London, UK, 2002.

74. Moragas, M.; Botella, M. (Eds.) Barcelona: L'herència dels Jocs. 1992-2002; Centre d'Estudis Olímpics UAB, Planeta: Barcelona, Spain; Turisme de Barcelona: Barcelona, Spain; Estadístiques de Turisme de Barcelona 2001: Barcelona, Spain; Turisme de Barcelona: Barcelona, Spain, 2002.

75. Malfas, M.; Theodoraki, E.; Houlihan, B. Impacts of the Olympic Games as Mega-Event. Munic. Eng. 2004, 157, 209-220. [CrossRef]

76. Sebata, E. The Barcelona Effect on Uganda's Sport Tourism Outlook: A Case of the2015 Barcelona vs. Uganda Legends Match. J. Tour. Hosp. 2016, 5, 1. [CrossRef]

77. Dawson, J.; Jöns, H. Unravelling legacy: A triadic actor-network theory approach to understanding the outcomes of mega events. J. Sport Tour. 2018, 22, 43-65. [CrossRef]

78. Njoroge, J.M.; Atieno, L.; Vieira Do Nascimento, D. Sports tourism and perceived socio-economic impact in Kenya: The case of Machakos county. Tour. Hosp. Manag. 2017, 23, 195-217. [CrossRef] 
79. Ritchie, B.W.; Shipway, R.; Cleeve, B. Resident perceptions of mega sporting events: A nonhost city perspective of the 2012 London Olympic Games. J. Sport Tour. 2009, 14, 143-167. [CrossRef]

80. Clark, J.; Kearns, A. Pathways to a physical activity legacy: Assessing the regeneration potential of multi-sport events using a prospective approach. Loc. Econ. 2015, 30, 888-909. [CrossRef]

81. Wise, N. Editorial: Tourism and Social Regeneration. Soc. Sci. 2018, 7, 262. [CrossRef]

82. Lesjak, M.; Podovšovnik Axelsson, E.; Uran, M. The perceived social impacts of the EuroBasket 2013 on Koper residents. Acad. Turist.-Tour. Innov. J. 2014, 7, 53-68.

83. Haynes, J. Socio-economic impact of the Sydney 2000 Olympic Games. Barcelona: Centre d'Estudis Olímpics UAB 2001. Available online: http://olympicstudies.uab.es/pdf/wp094_eng.pdf (accessed on 27 October 2012).

84. Liu, D.; Wilson, R. The negative impacts of hosting mega-sporting events and intention to travel: A test of thecrowding-out effect using the London 2012 Games as an example. Int. J. Sports Mark. Spons. 2014, 15, 12-26. [CrossRef]

85. French, S.; Disher, M. Atlanta and the Olympics: A One-year Retrospective. J. Am. Plan. Assoc. 1997, 63, 379-392. [CrossRef]

86. Henderson, J.C.; Foo, K.; Lim, H.; Yip, S. Sports events and tourism: The Singapore Formula One Grand Prix. Int. J. Event Festiv. Manag. 2010, 1, 60-73. [CrossRef]

87. Müller, M. Approaching paradox: Loving and hating mega-events. Tour. Manag. 2017, 63, $234-241$. [CrossRef]

88. Djaballah, M.; Hautbois, C.; Desbordes, M. Non-mega sporting events' social impacts: A sensemaking approach of local governments' perceptions and strategies. Eur. Sport Manag. Q. 2015, 15, 1-29. [CrossRef]

89. Zarębski, P.; Kwiatkowski, G.; Malchrowicz-Mośko, E.; Oklevik, O. Tourism investment gaps in Poland. Sustainability 2019, 11, 6188. [CrossRef]

90. Malchrowicz-Mośko, E.; Poczta, J. Running as a Form of Therapy Socio-Psychological Functions of Mass Running Events for Men and Women. Int. J. Environ. Res. Public Health 2018, 15, 2262. [CrossRef]

91. Poczta, J.; Malchrowicz-Mośko, E. Modern Running Events in Sustainable Development—More than Just Taking Care of Health and Physical Condition (Poznan Half Marathon Case Study). Sustainability 2018, 10, 2145. [CrossRef]

92. Malchrowicz-Mośko, E.; Młodzik, M.; León-Guereño, P.; Adamczewska, K. Male and female motivations for participating in a mass cycling race for amateurs. The Skoda Bike Challenge case study. Sustainability 2019, 11, 6635. [CrossRef]

93. Malchrowicz-Mośko, E.; Płoszaj, K.; Firek, W. Citius, Altius, Fortius vs. Slow Sport: A New Era of Sustainable Sport. Int. J. Environ. Res. Public Health 2018, 15, 2414. [CrossRef]

94. Malchrowicz-Mośko, E.; Poczta, J.; Adamczewska, K. The potential of non-mega sporting events for the promotion of physical activity among inactive supporters at the Poznan half marathon: A case study. Int. J. Environ. Res. Public Health 2019, 16, 4139. [CrossRef]

95. Malchrowicz-Mośko, E.; Chlebosz, K. Sport spectator consumption and sustainable management of sport event tourism. Fan motivation in high performance sport and non-elite sport. A case study of horseback riding and running-A comparative analysis. Sustainability 2019, 11, 2178. [CrossRef]

96. Malchrowicz-Mośko, E.; Botiková, Z.; Poczta, J. Because We Don't Want to Run in Smog: Problems with the Sustainable Management of Sport Event Tourism in Protected Areas (A Case Study of National Parks in Poland and Slovakia). Sustainability 2019, 11, 325. [CrossRef]

97. Malchrowicz-Mośko, E.; Poczta, J. A Small-Scale Event and a Big Impact-Is This Relationship Possible in theWorld of Sport? The Meaning of Heritage Sporting Events for Sustainable Development of Tourism-Experiences from Poland. Sustainability 2018, 10, 4289. [CrossRef]

98. Margaritis, G.; Rozmiarek, M.; Malchrowicz-Mośko, E. Tangible and Intangible Legacy of the 19th Century Zappas Olympics and their Implications for Contemporary Sport Tourism Physical Culture and Sport. Stud. Res. 2017, 74. [CrossRef]

99. Chalip, L.; Green, B.C.; Hill, B. Effects of Sport Event Media on Destination Image and Intention to Visit. J. Sport Manag. 2003, 17, 214-234. [CrossRef]

100. Brown, A.; Massey, J. Literature Review: The Impact of Major Sporting Events; Manchester Institute for Popular Culture, Manchester Metropolitan University: Manchester, UK, 2001. 
101. Coalter, F.; Taylor, J. Large Scale Sports Events: Event Impact Framework; Report to UK Sport. Research Report; University of Stirling: London, UK, 2008; Available online: http://hdl.handle.net/1893/1942 (accessed on 12 September 2019).

102. Cornelissen, S.; Bob, U.; Swart, K. Towards Redefining the Concept of Legacy in Relation to Sport Mega-Events: Insights from the 2010 FIFA World Cup. Dev. South Afr. 2011, 28, 307-318. [CrossRef]

103. Taks, M.; Littlejohn, M.; Wiood, L.; Snelgrove, R. Construct Validity of Social ImpactScales of Sport Events; Working Paper; University of Windsor Repository: Windsor, ON, Canada, 2016; Available online: http: //scholar.uwindsor.ca/humankineticspub (accessed on 15 September 2019).

104. Gratton, C.; Shibli, S.; Coleman, R. Sport and economic regeneration in cities. Urban Stud. 2005, 42, 985-999. [CrossRef]

105. Duglio, S.; Beltramo, R. Estimating the Economic Impacts of a Small-Scale Sport Tourism Event: The Case of the Italo-Swiss Mountain Trail CollonTrek. Sustainability 2017, 9, 343. [CrossRef]

106. O'Brien, D. Points of leverage: Maximizing host community benefit from a regional surfing festival. Eur. Sport Manag. Q. 2007, 7, 141-165. [CrossRef]

107. Higham, J. Commentary-sport as an avenue of tourism development: An analysis of the positive and negative impacts of sport tourism. Curr. Issues Tour. 1999, 2, 82-90. [CrossRef]

108. Kasimati, E. Economic aspects and the Summer Olympics: A review of related research. Int. J. Tour. Res. 2003, 5, 433-444. [CrossRef]

109. Minnaert, L. An Olympic legacy for all? The non-infrastructural outcomes of the Olympic Games for socially excluded groups (Atlanta 1996-Beijing 2008). Tour. Manag. 2012, 33, 361-370. [CrossRef]

110. Glynn, M.A. Configuring the field of play: How hosting the Olympic Games impacts civic community. J. Manag. Stud. 2008, 45, 1117-1146. [CrossRef]

111. Freyer, W.; Gross, S. (Eds.) Tourismus und Sport-Events; FIT Forschungsinstitut für Tourismus: Dresden, Germany, 2002; ISBN 978-3-925958-28-1.

112. Zawadzki, K. Ekonomiczne Efekty Organizacji Wielkoformatowych Wydarze n Sportowych, Monografie 164/Economic Effects of the Organization of Large-Format Sporting Events; Gdansk Politechnics: Gdansk, Poland, 2017; pp. 59-60. ISBN 978-83-7348-708-6.

113. Matheson, V.A.; Baade, R.A. Mega-Sporting Events in Developing Nations: Playing the Way to Prosperity? South Afr. J. Econ. 2004, 72, 1085-1096. [CrossRef]

114. Ramdas, B.; Reinette van Gaalen, R.; Bolton, J. The Announcement Impact of Hosting the FIFA World Cup on Host Country Stock Markets. Procedia Econ. Financ. 2015, 30, 226-238. [CrossRef]

115. Despiney, B.; Karpa, W. Estimating Economic Regional Effects of Euro 2012: Ex-ante and Ex-post, Management and Business Administration. Cent. Eur. 2014, 22, 3-15. [CrossRef]

116. Zawadzki, K. Euro 2012 Economic Impact on Host Cities in Poland; LAP Lambert Academic Publishing: Saarbruecken, Germany, 2013; 129p, Available online: https://mpra.ub.uni-muenchen.de/id/eprint/64522 (accessed on 15 September 2019).

117. Brunet, F. The Economic Impact of the Barcelona Olympic Games, Barcelona: The legacy of the Games 1992-2002; Centre d'Estudis Olímpics UAB: Barcelona, Spain, 2002.

118. Maennig, W.; Zimbalist, A. International Handbook on the Economics of Mega Sporting Events; Edward Elgar Publishing: Cheltenham, UK, 2012.

119. Matheson, V.A. Mega-Events: The Effect of the World's Biggest Sporting Events on Local, Regional and National Economies; Holy CrossWorking Paper Series; Holy Cross: Worcester, MA, USA, 2006.

120. Toman, T.; Borzyszkowski, J. Wptyw Mistrzostw Europy w Piłce Nożnej EURO 2012 na Rynek Turystyczny Trójmiasta w Opinii Mieszkańców Aglomeracji; Turystyka Kulturowa nr 3/2012, KulTour.pl—Organizator Turystyki Kulturowej i Edukacyjnej: Poznań, Poland, 2012.

121. Borzyszkowski, J. Mistrzostwa Europy w Piłce Nożnej UEFA EURO 2012 a Turystyka w Polsce-Wstępna Ocena, Turystyka Kulturowa 2012. Volume 9, pp. 55-68. Available online: http://turystykakulturowa.org/ojs/ index.php/tk/article/view/304 (accessed on 15 September 2019).

122. Huang, H.C.; Lai, Y.H.; Chen, L.S.; Chang, C.M. Influence of International Mega Sport Event towards Cognition of Economic, Social-Cultural and Environmental Impact for Residents: A Case Study of the 2009 Kaohsiung World Games. Adv. Mater. Res. 2012, 524-527, 3392-3397. [CrossRef] 
123. Malchrowicz-Mośko, E.; Gravelle, F.; Dąbrowska, A.; León-Guereño, P. Do Years of Running Experience Influence the Motivations of Amateur Marathon Athletes? Int. J. Environ. Res. Public Health 2020, 17, 585. [CrossRef]

124. Kazimierczak, M.; Dąbrowska, A.; Adamczewska, K.; Malchrowicz-Mośko, E. The Impact of Modern Ultramarathons on Shaping the Social Identity of Runners. The Case Study of Karkonosze Winter Ultramarathon. Int. J. Environ. Res. Public Health 2020, 17, 116. [CrossRef]

125. Gibson, H.; Kaplanidou, K.; Kang, S.J. Small-scale event sport tourism: A case study in sustainable tourism. Sport Manag. Rev. 2012, 15, 160-170. [CrossRef]

126. Kwiatkowski, G.; Oklevik, O. Primary Economic Impact of Small-scale Sports Events. Event Manag. 2017, 21, 269-280. [CrossRef]

127. Hinch, T.; Higham, J. Sport and Tourism—Globalization, Mobility and Identity; Elsevier: Burlington, NJ, USA, 2009.

128. Hinch, T.; Higham, J. Sport Tourism Development; Channel View Publications: Bristol, UK, 2011.

129. Hinch, T.; Higham, J. Sport tourism and sustainable destinations: Foundations and pathways. J. Sport Tour. 2016, 20, 3-4. [CrossRef]

130. Weed, M. Sport Tourism Experience. J. Sport Tour. 2008, 13, 1-4. [CrossRef]

131. Liu, D. The image impact of mega-sporting events perceived by international students and their behaviour intentions. Int. J. Sports Mark. Spons. 2015, 16, 22-36. [CrossRef]

132. Mao, L.L.; Huang, H. Social impact of Formula One Chinese Grand Prix: A comparison of local residents? perceptions based on the intrinsic dimension. Sport Manag. Rev. 2016, 19, 306-318. [CrossRef]

133. Liu, D. Development of a scale measuring the psychic income associated with hosting the Olympic Games. Int. J. Sports Mark. Spons. 2017, 18, 298-313. [CrossRef]

134. Anne-Line, B.; Marc, M.; Marc, B. The Social Impact of the Tour de France: Comparisons of Residents' Preand Post-event Perceptions. Eur. Sport Manag. Q. 2011, 11, 91-113. [CrossRef]

135. Faulkner, B.; Tideswell, C. A framework for monitoring community impacts of tourism. J. Sust. Tour. 1997, 5, 3-28. [CrossRef]

136. Bynner, J. Use of Longitudinal Data in the Study of Social Exclusion. Centre for Longitudinal Studies, Institute of Education. 1996. Available online: http://www.oecd.org/education/innovation-education/1856691.pdf (accessed on 14 September 2019).

137. Homans, G.C. Social Behaviours: Its Elementary Forms; Harcourt, Brace: New York, NY, USA, 1996.

138. Perdue, R.R.; Long, P.T.; Allen, L. Resident support for tourism development. Ann. Tour. Res. 1990, 17, 586-599. [CrossRef]

139. Harrill, R. Residents' attitudes toward tourism development: A literature review with implication for tourism planning. J. Plan. Lit. 2004, 18, 251-266. [CrossRef]

140. Ap, J. Residents' perceptions on tourism impacts. Ann. Tour. Res. 1992, 19, 665-690. [CrossRef]

141. Teye, V.; Sommez, S.F.; Sirakaya, E. Residents' attitudes towards tourism development. Ann. Tour. Res. 2002, 29, 668-688. [CrossRef]

142. Waitt, G. Social Impacts of the Sydney Olympics. Ann. Tour. Res. 2003, 30, 194-215. [CrossRef]

143. Glasson, J.; Therivel, R.; Chadwick, A. Introduction to Environmental Impact Assessment; Routledge: Abingdon, UK, 2005. [CrossRef]

(C) 2020 by the authors. Licensee MDPI, Basel, Switzerland. This article is an open access article distributed under the terms and conditions of the Creative Commons Attribution (CC BY) license (http://creativecommons.org/licenses/by/4.0/). 